\title{
1 Bionomics of Aedes aegypti during the 2016-2017 dengue outbreaks in
}

Athanase Badolo ${ }^{1 \#}$, Aboubacar Sombié ${ }^{1}$, Félix Yaméogo ${ }^{\S 1}$, Dimitri W. Wangrawa ${ }^{\$ 1,2}$, Aboubakar Sanon $^{1}$, Patricia M. Pignatelli ${ }^{3}$, Antoine Sanon ${ }^{1}$, Mafalda Viana ${ }^{4}$, Hirotaka Kanuka, ${ }^{5,6}$, David Weetman $*^{3}$, Philip J. McCall $*^{3}$

${ }^{1}$ Laboratoire d'Entomologie Fondamentale et Appliquée, Université Joseph Ki-Zerbo, Burkina Faso ${ }^{2}$ Université Norbert Zongo, Koudougou, Burkina Faso

${ }^{3}$ Department of Vector Biology, Liverpool School of Tropical Medicine, Liverpool, UK

${ }^{4}$ Institute of Biodiversity, Animal Health and Comparative Medicine, University of Glasgow

${ }^{5}$ Department of Tropical Medicine, The Jikei University School of Medicine, Tokyo, Japan

${ }^{6}$ Center for Medical Entomology, The Jikei University School of Medicine, Tokyo, Japan

${ }^{\#}$ Corresponding author

E-mail: a.badolo@gmail.com

*These authors contributed equally

${ }^{\S}$ These authors contributed equally

\begin{abstract}
Background Dengue's emergence in West Africa was typified by the Burkina Faso outbreaks in 2016 and 2017, the nation's largest to date. In both years, we undertook three-month surveys of Aedes populations in or near the capital city Ouagadougou, where the outbreak was centered.
\end{abstract}

Methodology In urban, peri-urban and rural localities we collected indoor and outdoor resting mosquito adults, characterized larval habitats and containers producing pupae and reared immature stages to adulthood in the laboratory for identification. All mosquito adults were identified morphologically. Host species from which bloodmeals were taken were identified by PCR Generalized mixed models were used to investigate relationships between adult or larval densities and multiple explanatory variables.

Results From samples in 1,791 houses, Ae. aegypti was the most abundant mosquito in the two urban localities where it occurred in $46 \%$ of containers sampled and comprised over $85 \%$ of collections. Results indicated a highly exophilic and anthropophilic ( $>90 \%$ bloodmeals of human origin) vector population, but with a relatively high proportion of bloodfed females caught inside houses. Habitats producing most pupae were waste tires (37\% of total pupae), animal troughs (44\%) and large water barrels (30\%).

While Stegomyia indices were not reliable indicators of adult mosquito abundance, shared influences on adult and immature stage densities included rainfall and container water level, collection month and container type/ purpose. Spatial analysis showed autocorrelation of densities, with partial overlap in adult and immature stage hotspots.

Conclusion Results provide an evidence base for the selection of appropriate vector control methods to minimize the risk, frequency and magnitude of future outbreaks in Ouagadougou. An integrated strategy combining community-driven practices, waste disposal and insecticide-based interventions is indicated. The prospects of developing a regional approach to arbovirus control in west Africa or across Africa was discussed 
medRxiv preprint doi: https://doi.org/10.1101/2021.12.14.21267559; this version posted December 16, 2021. The copyright holder for this preprint (which was not certified by peer review) is the author/funder, who has granted medRxiv a license to display the preprint in perpetuity. All rights reserved. No reuse allowed without permission.

49

\section{Author Summary}

Aedes aegypti is the most efficient vector of human diseases including yellow fever, dengue chikungunya and Zika. West Africa is an emerging hotspot for dengue, as illustrated by Burkina Faso's outbreaks in 2016 and 2017. Coincidentally, this study investigated the bionomics and behavior of Ae. aegypti in urban, peri-urban and rural localities of Ouagadougou, from August to October in each year. The results from over 1700 homes showed that Ae. aegypti preferentially fed on humans and rested primarily outdoors. The most common pupal productive habitats were discarded vehicle tires, animal water troughs and large water barrels. Infestation rates were higher in the urban and peri-urban localities. A range of community-based control measures are suitable for consideration in a vector control program to prevent outbreaks. Further work is required but the study provides the most complete contemporary description of an Ae. aegypti population in West Africa and provides sufficient evidence to develop programs for prevention and control of outbreaks. The potential of a regional based vector control program for west Africa is discussed briefly. 
medRxiv preprint doi: https://doi.org/10.1101/2021.12.14.21267559; this version posted December 16, 2021. The copyright holder for this

\section{Background}

Aedes aegypti mosquitoes thrive in urban environments throughout the tropics and sub-tropics, where they are the primary human vectors of dengue, Zika, chikungunya and urban yellow fever arboviruses. Dengue is the most widespread and an estimated annual toll of 400 million infections, and a threat to almost half of the human population at risk globally $[1,2]$. Driven by climate change, further increases are predicted [3] and the search for effective and sustainable methods to control peridomestic Aedes populations has become a primary global health challenge.

The worldwide expansion in Aedes aegypti populations in the late twentieth century followed a period when the human population grew at an unprecedented rate, mainly in cities, environments where this vector also could flourish [4,5]. Increases in global trade and human travel, particularly access to affordable and rapid intercontinental air travel, transferred multiple strains of arboviruses far beyond their original ranges into immunologically naïve populations [6], while climate change increased outbreak risk in new areas out the tropics $[7,8]$. With almost 500 million people already living in its cities and a population doubling-rate of 25 years, sub-Saharan Africa has the fastest urbanization growth rate worldwide $[9,10]$. In many countries, sylvatic cycles of yellow fever frequently initiate outbreaks [11-16] that threaten urban areas where human to human transmission by Ae. aegypti would result in frequent outbreaks, were it not for an effective vaccine $[17,18]$.

There have been significant outbreaks of chikungunya in countries of East, South and North Africa [19-22] and increasingly, reports of Zika [23,24]. Indeed, better diagnostic methods are revealing that chikungunya infections, though causing little mortality, are responsible for greater morbidity and a higher-disease burden than previously suspected [6]. Dengue presents the greatest arboviral threat to Africa, with West Africa identified as a potential dengue transmission hotspot, based on its rapid rate of unplanned urbanization, widespread occurrence of Aedes vectors, history of arbovirus transmission and poor clinical knowledge of flavivirus infections [25].

The vast majority of recent knowledge of Aedes aegypti was generated by studies in Asia and Latin America [26-29], and may not be transferred reliably to African Ae. aegypti populations [30]. The 
medRxiv preprint doi: https://doi.org/10.1101/2021.12.14.21267559; this version posted December 16, 2021. The copyright holder for this

91 need for continent-specific knowledge is reinforced by growing evidence of the genetic and

92 phenotypic diversity of Ae. aegypti within Africa and differences in the epidemiology of Aedes-

93 borne diseases globally $[4,31,32]$.

94 Burkina Faso experienced dengue outbreaks in 2016, resulting in 2,600 cases and 21 deaths, and in

95 2017, resulting in 14,455 cases and 29 deaths [33,34]. The outbreak continued into 2018, with a

96 further 4,386 cases and 25 deaths. Though all four dengue virus serotypes had been recorded

97 previously in Burkina Faso [35], only types I, II and III were reported in the recent outbreak, of

98 which type II was the most prevalent [36].

99 In August 2016, we began a study on the bionomics of Ae. aegypti in Ouagadougou, the capital city

100 of Burkina Faso, with the objective of collecting baseline data for dengue control. Though not

101 planned that way, the study coincided with the dengue outbreaks in 2016 and 2017 and sampling

102 was carried out in locations where and while transmission was occurring. Here we report the results

103 of wet season investigations into the behavioral preferences and spatial distribution of Ae. aegypti

104 breeding and adult resting sites across different levels of urbanization, and use this evidence base to

105 develop an appropriate, effective and sustainable vector control strategy for Ouagadougou, suitable

106 for use as a regional template within a larger integrated vector management program.

107

108 Materials and Methods

109 Study Area.

110 Burkina Faso occupies three climatic zones: the Sahelian in the north, the central Soudano-Sahelian

111 zone and Soudanian in the south. The capital city Ouagadougou lies in the Soudano-Sahelian zone,

112 within the $500 \mathrm{~mm}$ isohyet where $350-750 \mathrm{~mm}$ rain falls between June and October. Three distinct

113 localities in or near the city were selected on the basis of house design and size, house density, and

114 land use, as representatives of urban, peri-urban and rural settings.

1151200 Logements: (1200 LG) $\left(12^{\circ} 22^{\prime} \mathrm{N} ; 1^{\circ} 29^{\prime} \mathrm{W}\right)$ is an urban setting of $1.2 \mathrm{~km}^{2}$ in central 
116 Ouagadougou, less than $1 \mathrm{~km}$ from the international airport. Roads are paved and the area is

117 connected to centralized water, waste and electricity systems. Houses are relatively modern single-

118 or two-storey and typically comprise one living room and 2-3 bedrooms, often with air

119 conditioning. Vegetation, often within gardens, is common on both private and common land.

120 Tabtenga: $\left(12^{\circ} 22^{\prime} \mathrm{N} ; 1^{\circ} 27^{\prime} \mathrm{W}\right)$ is a $10 \mathrm{~km}^{2}$ peri-urban setting located within Ouagadougou,

121 approximately $5 \mathrm{~km}$ east of 1200 LG. Roads are unpaved, there are no electricity or waste

122 management systems and the majority of households obtain water at communal pumps. Typical

123 households are single-storey structures with 1-4 rooms, within walled compounds. Vegetation is

124 sparse.

125 Goundry: $\left(12^{\circ} 30 \mathrm{~N}, 1^{\circ} 20 \mathrm{~W}\right)$ is a small rural farming community village situated $30 \mathrm{~km}$ north-east

126 of Ouagadougou, with unpaved roads, low housing density, and is surrounded by fields and trees.

127 There is a dam in the center of the villages enabling people to practice gardening during the dry

128 season. Goundry has no electricity or waste management systems and households obtain water at

129 communal pumps. Livestock, mainly cattle and sheep, and dogs are common.

\section{Study Design}

131 Longitudinal surveys were carried out during the wet season from August to October in both 2016

132 and 2017. Prior to each survey, all prospective houses were visited to inform the population of the

133 proposed project, and the proposed sampling procedures. Each day, the first house was selected at

134 random and the second and subsequent houses chosen where the family were present and agreed to

135 participate, avoiding the houses nearest to the previous one. An average of ten houses were visited

136 per day. Houses were sampled at 06:00-09:00 or 16:00-19:00 by two teams of four persons, each

137 working as follows: one person collected informed consent and household data (S1Table), a second

138 person searched for adult mosquitoes indoors and outdoors; two people recorded breeding habitat

139 characteristics and collected immature stages of mosquitoes. Areas of public or communal land

140 adjacent to sampled houses were mapped and inspected for containers, from which mosquito 
medRxiv preprint doi: https://doi.org/10.1101/2021.12.14.21267559; this version posted December 16, 2021. The copyright holder for this

141 immature stages were processed as described below.

142 Breeding site characterization and collection of immature mosquitoes

143 At each property, the team worked indoors and outdoors inspecting every container capable of

144 holding sufficient water for immature mosquitoes, recording its dimensions, water volume, water

145 level, material (natural, wood, metal, cement, etc.) and utility (whether the container was in use

146 (yes) or discarded waste (no)). Where possible, water from each container was poured into a

147 graduated beak and any immature mosquitoes collected using a sieve. The water volume of heavy

148 or immovable containers, including potable water, was measured by removal with buckets, again

149 using a sieve to collect all mosquitoes, before being returning to the container. All larvae and pupae

150 were transferred alive to containers labelled by house number and breeding site location, for

151 subsequent identification.

152 Breeding habitats were categorized using the WHO operational guide [28] with minor adaptations

153 to accommodate certain features observed in Ouagadougou as follows:

$154 \quad$ - Large containers - drums and barrels; water volume > $50 \mathrm{~L}$

155 - Medium containers - buckets, large pots and small drums; 10-49 L

156 - Small containers - all container types of any material $<10 \mathrm{~L}$,

$157 \quad-\quad$ Tires - stored or discarded vehicle tires

$158 \quad$ - Drinking troughs - water for livestock, of any material

$159 \quad$ - Other - ground water puddle, tree holes and flower pots

160 Stegomyia indices were calculated as defined by Focks[37]:

161 - House index (HI): defined as the percentage of houses infested with Aedes aegypti larvae

$162 \quad$ and/or pupae in a locality

163 - Container index (CI): the percentage of water-holding containers positive for immature

$164 \quad$ stages of Aedes aegypti 
medRxiv preprint doi: https://doi.org/10.1101/2021.12.14.21267559; this version posted December 16, 2021. The copyright holder for this

167 To identify the most productive dengue vector breeding sites, and to determine whether certain

168 habitats that were relatively more productive for pupae might be identified for future targeting, we

169 recorded pupae separately from larvae. Pupal mortality is typically low meaning that the number of

170 pupae is highly correlated with the number of adults [38]. To identify the most productive Ae.

171 aegypti immature stage habitats, the percentage contribution of each container type to the total

172 count of pupae is calculated as the total number of pupae per container type, divided by the total

173 number of pupae in all containers throughout the study area [28].

\section{Adult mosquito collection}

175 Using a Prokopack aspirator [39], all adult mosquitoes were collected from each house, animal

176 shelter and external kitchen. Indoors, wall surfaces, closet or cupboard interiors and other known

177 resting places [40], were inspected using flashlights, for a total of 10 minutes per household [41].

178 Outdoors, all walls, eaves, vegetation (flowers) and shaded areas within or behind containers, stored

179 materials, and car tires within the walled area marking the perimeter of each household were then

180 inspected for an additional 10 minutes.

\section{$181 \quad$ Processing and identification of collected mosquitoes}

182 All immature mosquito stages were sorted based on morphology then reared in cups with ground

183 Tetramin as food until adult emergence. Pupae were transferred to fresh cups and emerging adults

184 killed and preserved by freezing for identification.

185 Mosquitoes were identified by microscopy using morphological keys. Aedes aegypti [42-44] was

186 identified as described by Moore et al. [45] and all other culicine species were identified using

187 Edwards (1941). Anopheles species identification followed the keys of Gillies \& Coetzee [47] and

188 Diagne et al. [48]. The SINE method [49] was used to identify Anopheles gambiae complex

189 mosquitoes to species level. 
medRxiv preprint doi: https://doi.org/10.1101/2021.12.14.21267559; this version posted December 16, 2021. The copyright holder for this

\section{Identification of bloodmeal origin}

191 DNA was extracted from abdomens of bloodfed females using Qiagen DNEasy kits. Extracted

192 DNA served as template for amplification of the cytochrome b gene using human, cow, pig, dog,

193 goat and sheep species-specific primers in a cocktail PCR [50]. Each reaction contained $15.8 \mathrm{ul}$ of

194 water, 2.5ul of 10x DreamTaq buffer, $0.5 \mathrm{ul} 10 \mathrm{mM}$ of each dNTP, $0.5 \mathrm{ul}$ of $50 \mu \mathrm{M}$ of each primer;

1950.2 of 5U/ul DreamTaq and 3 ul of DNA for a total volume of 25 ul. The PCRs were run with the

196 program $95^{\circ} \mathrm{C}$ for $5 \mathrm{~min}$, then 50 cycles of $95^{\circ} \mathrm{C}$ for $60 \mathrm{~s}, 56^{\circ} \mathrm{C}$ for $60 \mathrm{~s}, 72^{\circ} \mathrm{C}$ for $60 \mathrm{~s}$, followed by a

197 final extension step of $72^{\circ} \mathrm{C}$ for $7 \mathrm{~min}$. Products were run on a $2 \%$ TAE-agarose gel, with band size

198 interpretation as follows: $334 \mathrm{bp}$ (human), $453 \mathrm{bp}$ (pig), $132 \mathrm{bp}$ (goat or sheep), $680 \mathrm{bp}$ (dog), 561

199 bp (cow). PCR products of positive bloodmeals that gave unclear gel banding-patterns were

200 sequenced using universal vertebrate primers [50], aligned using codon code aligner v 4.7

201 (Codoncode corp., USA) and their species of origin identified using NCBI BLAST searches.

\section{Ethical approvals}

203 The study protocol received ethical approval from the National Ethical Committee (Comité

204 National d'Ethique pour la Recherche en Santé), Ministry of Health, Burkina Faso (Deliberation

205 No. 2016-6-073; 6th June 2016) and from the Liverpool School of Tropical Medicine Research

206 Ethics Committee for "Dengue in Burkina Faso: establishing a vector biology evidence base for risk

207 assessment and vector control strategies for an emerging disease“ (Research Protocol 16-30; 15th

208 July 2016).

209

210

\section{Meteorological data}

Daily records of minimal, maximal, mean temperatures, relative humidity and daily rainfall were obtained from the National Meteorological Agency records from Ouagadougou station for 2016 and 2017. Intermediate calculations were made for the cumulative rainfall for previous 4 days, one week, 12 days or 14 days to be included in the models. 
To investigate factors associated with Aedes sp. abundance we developed four Generalised Linear

216 Mixed Models (GLMMs) with a negative binomial link function using the R package "glmmTMB".

217 The first (adult model) and second (bloodfed model) were fitted to the number of adults and

218 bloodfed Aedes collected in each house, respectively, as a function of the abiotic and biotic

219 covariates: the year of collection, locality (1200 LG, Tabtenga, Goundry), house type (mixed,

220 modern or traditional), location (indoors/outdoors), day of collection, month of collection, the

221 number of larvae collected in breeding sites located in that house, and also climate factors including

222 temperature and cumulative rainfall. The interaction terms 'collection location' and locality, and

223 locality and year were also included, and to account for variation arising from the sampling design

224 we included date of collection and house identifier as random effects. The third (larval model) and

225 fourth (pupal model) models were fitted to the number of larvae and pupae per container,

226 respectively, as a function of the abiotic and biotic covariates: locality, container type, water level,

227 water volume, container material, the 'location' (i.e. indoors/outdoors) of the containers utility,

228 rainfall and temperature, number of adults collected in the house. As in the adult mosquito model,

229 the variables location and locality, and year and locality were also included as interaction terms, and

230 date of collection and house identifier were added as random effects.

231 From these full models we selected the minimal model using a stepwise backward model selection

232 procedure based on the lowest AIC values by removing factors with highest $\mathrm{p}$-value in the model. If

233 removing a variable resulted in a change of the AIC value of more than 2 and the resultant model

234 was still parsimonious. e.g. following residuals diagnostics in DHARMa [51], the simplified model

235 was kept. This procedure was repeated until removing variables no longer improved the model.

236 To ensure the models described above were appropriate, we also explored the use of alternative

237 families such as poisson and quasipoisson, but DHARMa residuals diagnostics indicated that these

238 failed to capture the dispersion in data. We tested for spatial autocorrelation both in the data and

239 residuals of the models using the Moran's I test [52] and found no significant spatial autocorrelation

240 (for a p-value of 0.05), hence inclusion of a spatial term was not required. Finally, we estimated the 
correlation among our potential covariates, if two variables were $>50 \%$ correlated, one of them was

242 excluded from the final full model. These included temperature and relative humidity, immatures

243 total number and larvae number, number of residents and number of children. Since larvae and

244 immatures were correlated (53\%), for the adult model we used the covariate 'immatures' (sum of

245 larvae and pupae).

246 To estimate the overlap between the spatial distributions of adult and immature stages, we used the

247 “nicheOverlap” function in the R package 'dismo' [53], which estimates an index of similarity

248 between rasterized density distributions based on [54], and calculated the Pearson correlation

249 coefficient between these two distributions using the 'layerStats' function in the package 'raster'

$250 \quad[55]$.

251 To analyse whether the location of blood-feeding (indoor vs outdoors) was in line with collection

252 densities, the expected numbers of indoor blood fed females were predicted from the total bloodfed

253 collections in each year and locality multiplied by the relative indoor density. A chi-square

254 goodness of fit test was used to determine whether observed values deviated from predictions.

255 Other comparisons between proportions used chi-square contingency table tests or Fisher exact tests

256 (depending on the expected values). Stegomyia index results were compared among localities using

257 non-overlapping confidence intervals as indicative of a significant difference.

Results

Characteristics of sampled houses

261 A total of 1,163 houses were sampled in 2016 and 631 in 2017, plus an additional 24 public spaces

262 in 2017 (S1Table), including among others, places of worship, schools, market stalls and stores. All

263 houses in 1200 LG (urban) were cement block buildings of modern designs, whereas the houses in

264 Tabtenga (peri-urban) and Goundry (rural) were a mix of traditional adobe houses and modern

265 houses. Average occupancy rates in each locality in 2016 were 5.3, 5.0 and 2.9 residents per house, 
medRxiv preprint doi: https://doi.org/10.1101/2021.12.14.21267559; this version posted December 16, 2021. The copyright holder for this preprint (which was not certified by peer review) is the author/funder, who has granted medRxiv a license to display the preprint in perpetuity.

All rights reserved. No reuse allowed without permission.

266

267

268

269

270

271

272

273

274

275

276

277

278

279

280

281

282

283

284

285

286

287

288

289

290

291

and insecticide-treated nets (ITNs) were seen in $75.9 \%, 91.5 \%$ and $75.9 \%$ of houses, with an average of $0.44,0.43$ and 0.43 ITNs per person, respectively. In 2017, the average occupancy rates in each locality were 5.2, 6.2 and 3.3, and ITNs were seen in $60.6 \%, 87.8 \%$ and $88.7 \%$ respectively, with an average 0.36 ITNs per person in each localities.

\section{Adult mosquito species abundance}

A total of 47,255 adult mosquitoes were collected during both years in all localities by indoor and outdoor resting catches (Table 1). Aedes aegypti abundance varied between the sampling localities in both years $\left(2016: \chi_{2}^{2}=187.1 ; \mathrm{P}<<0.001 ; 2017: \chi_{2}^{2}=165.2 ; \mathrm{P}<<0.001\right)$. Adult Ae. aegypti were more abundant in 1200 LG and Tabtenga, where they comprised between 9.3 and $12.8 \%$ of the total catch, at house infestation rates of between 63.1 and 77.2\%. Collections in Goundry were consistently lower than in the urban and peri-urban sites, comprising less than $5 \%$ of the total number of mosquitoes caught, with house infestation rates of less than $20.8 \%$. Low numbers of other Aedes species were collected, mainly in Goundry, and included Aedes vittatus, Aedes hirsutus, and Aedes metallicus (Table 1).

Catches of other mosquitoes were dominated by Culex quinquefasciatus and Anopheles gambiae s.l. (Table 1). Culex quinquefasciatus was by far the most abundant mosquito in the two urbanised sites, 1200 LG and Tabtenga, where it comprised approximately $80 \%$ of the total collections. In rural Goundry, numbers of $C x$. quinquefasciatus were significantly lower, comprising less than $25 \%$ of catches $\left(\chi_{1}^{2}=191.9, \mathrm{P}<<0.001\right)$. In contrast, the proportions of An. gambiae s.l. in catches at Goundry were over ten times greater than at the urban and peri-urban localities (56\% vs. 4\%; $\left.\chi_{1}^{2}=11.34, \mathrm{P}<<0.001\right)$. Molecular identification of Anopheles gambiae complex mosquitoes revealed significant variation in species composition too $\left(\chi_{4}^{2}=127, \mathrm{P}<<0.001\right)$ with the highest proportions of An. coluzzii seen at Goundry, whereas An. arabiensis was the dominant species in Tabtenga and 1200 LG (Table 1). Other Anopheles species (Anopheles rufipes, Anopheles funestus and Anopheles ziemani) and the predatory culicine Lutzia tigripes were recorded much more frequently in Goundry $1.2 \%$ vs $0.1 \%$; Table 1 ). 
Table 1. Species, number and proportion of adult mosquitoes collected indoors and outdoors in three localities of Ouagadougou in 2016 and 2017. Proportions were calculated only for the most common vector species Aedes aegypti, Anopheles gambiae, Culex quinquefasciatus.

${ }^{1}$ Other Aedes were Ae vittatus, Ae hirsutus and Ae metallicus; Anopheles ${ }^{2}$ were An. rufipes, An. funestus and An. ziemanii.

\begin{tabular}{|c|c|c|c|c|c|c|}
\hline \multirow[b]{2}{*}{ Species } & \multicolumn{2}{|l|}{ 1200LG (Urban) } & \multicolumn{2}{|c|}{ Tabtenga (Peri-urban) } & \multicolumn{2}{|l|}{ Goundry (Rural) } \\
\hline & 2016 & 2017 & 2016 & 2017 & 2016 & $2017 \quad 297$ \\
\hline Aedes aegypti & $1811(11.11 \%)$ & $782(12.56 \%)$ & $976(9.33 \%)$ & $963(12.80 \%)$ & $137(3.75 \%)$ & $143(4.56 \%)$ \\
\hline Other Aedes ${ }^{1}$ & 17 & 1 & 8 & 3 & 35 & $46 \quad 298$ \\
\hline Anopheles gambiae s.l. & $585(3.59 \%)$ & $143(2.30 \%)$ & $601(5.74 \%)$ & $237(3.15 \%)$ & $2,107(57.72 \%)$ & $1,659(52.87 \%)$ \\
\hline Anopheles arabiensis & $100(95.24 \%)$ & & $102(92.73 \%)$ & & $37(37.37 \%)$ & \\
\hline Anopheles coluzzii & $3(2.86 \%)$ & & $3(2.73 \%)$ & & $53(53.54 \%)$ & \\
\hline Anopheles gambiae & $2(1.90 \%)$ & & $5(4.55 \%)$ & & $9(9.09 \%)$ & \\
\hline Other Anopheles $^{2}$ & 3 & 1 & 6 & 2 & 66 & 132 \\
\hline Culex quinquefasciatus & $13,877(85.13 \%)$ & $4,244(68.14 \%)$ & $8,864(84.71 \%)$ & $5,834(77.55 \%)$ & $1,128(30.90 \%)$ & $507(16.16 \%)$ \\
\hline Other Culex & 8 & 1047 & 6 & 477 & 140 & 574 \\
\hline Lutzia tigripes & 0 & 8 & 0 & 7 & 36 & 30 \\
\hline Mansonia sp. & 0 & 2 & 1 & 0 & 0 & 1 \\
\hline Total collected & 16,301 & 6,228 & 10,462 & 7,523 & 3,649 & 3,092 \\
\hline
\end{tabular}


medRxiv preprint doi: https://doi.org/10.1101/2021.12.14.21267559; this version posted December 16, 2021. The copyright holder for this preprint (which was not certified by peer review) is the author/funder, who has granted medRxiv a license to display the preprint in perpetuity.

All rights reserved. No reuse allowed without permission.

\section{Resting location and diurnal activity of adult Aedes aegypti}

300 Significantly more adult female Ae. aegypti were collected resting outdoors than indoors in all

301 localities in each year (S2Table), with a remarkably consistent proportion outdoors each year

302 (mean=0.73 in both 2016 and 2017), equivalent to an outdoor: indoor ratio of 2.7-fold (binomial

303 test $\mathrm{P}<0.001)$. As can be seen in Figure 1 differences in relative proportions caught indoor and

304 outdoor varied among localities $\left(\chi_{2}^{2}=149,<0.001\right)$, with a consistently lower, but still strongly

305 exophilic-biased, ratio in Tabtenga.

306

307 Figure 1. Indoor and outdoor resting behavior of adult female Ae. aegypti in domestic housing

308 in Ouagadougou. Geometric means and 95\% confidence limits of numbers of Ae. aegypti adults

309 collected indoors and outdoors per house, in the three localities in 2016 and 2017.

311 However, the proportion of bloodfed females caught outdoor was only slightly greater than those

312 indoor (ratio $=1.05$ ), which represents approximately twice the expected number predicted from

313 the total indoor: outdoor catch ratio (Table 2). This suggests that a preference for exophily may not

314 be sustained through the entire gonotrophic cycle.

315 Trends in morning vs. afternoon collections of Ae. aegypti were inconsistent across years (S3Table).

316 In 2016, there appeared to be a bias toward morning collections (59.6\%; binomial test, $\mathrm{P}<0.001)$,

317 but in 2017 morning and afternoon collections were very similar (50.3\%; binomial test, $\mathrm{P}=0.83$ ).

318 Similarly, strong variation between localities in morning:afternoon collections was evident in 2016,

319 with relatively morning biased collections in the urban and peri-urban sites but afternoon-biased in

320 Goundry $\left(\chi_{2}^{2}=497, \mathrm{P}<0.001\right)$, but was barely-evident in $2017\left(\chi_{2}^{2}=6.1, \mathrm{P}=0.047\right)$. 


\section{Table 2: Numbers of bloodfed Aedes aegypti and density/house in indoor and outdoor resting §collections in domestic housing in}

Ouagadougou. The expected number of bloodfed mosquitoes indoors was calculated from the proportion caught indoors and compared to observed numbers bloodfed using a chi-square goodness of fit test.

\begin{tabular}{|c|c|c|c|c|c|c|c|c|c|c|c|c|}
\hline \multirow{2}{*}{ Year } & \multirow[b]{2}{*}{ Locality } & \multicolumn{4}{|c|}{ Observed blood fed } & \multicolumn{4}{|c|}{ Observed density } & \multirow{2}{*}{$\begin{array}{c}\text { Proportion } \\
\text { caught }\end{array}$} & \multirow{2}{*}{$\begin{array}{l}\text { Expected } \\
\text { bloodfed }\end{array}$} & \multirow{2}{*}{$\begin{array}{r}326 \\
327 \\
X^{2}\end{array}$} \\
\hline & & Indoor & Outdoor & total & $\%$ indoor & Indoor & Outdoor & total & $\%$ indoor & & & \\
\hline \multirow[t]{3}{*}{2016} & 1200LG & 118 & 186 & 304 & 0.39 & 0.51 & 1.79 & 2.30 & 0.22 & 0.22 & 67.41 & 37.928 \\
\hline & Tabtenga & 110 & 92 & 202 & 0.54 & 0.48 & 0.83 & 1.31 & 0.37 & 0.37 & 74.02 & 17.50 \\
\hline & Goundry & 5 & 13 & 18 & 0.28 & 0.04 & 0.16 & 0.20 & 0.20 & 0.20 & 3.60 & 0.54 \\
\hline \multirow[t]{6}{*}{2017} & $1200 \mathrm{LG}$ & 42 & 59 & 101 & 0.42 & 0.37 & 1.86 & 2.23 & 0.17 & 0.17 & 16.76 & 38.02 \\
\hline & Tabtenga & 111 & 55 & 166 & 0.67 & 0.67 & 0.89 & 1.56 & 0.43 & 0.43 & 71.29 & 22.11 \\
\hline & Rural & 3 & 4 & 7 & 0.43 & 0.05 & 0.28 & 0.33 & 0.15 & 0.15 & 1.06 & 3.55 \\
\hline & & & & & & & & & & & total & 119.69 \\
\hline & & & & & & & & & & & $\mathrm{df}$ & 5 \\
\hline & & & & & & & & & & & $P$ & $<<0.001$ \\
\hline
\end{tabular}


medRxiv preprint doi: https://doi.org/10.1101/2021.12.14.21267559; this version posted December 16, 2021. The copyright holder for this preprint (which was not certified by peer review) is the author/funder, who has granted medRxiv a license to display the preprint in perpetuity.

All rights reserved. No reuse allowed without permission.

\section{Host preference of adult Aedes aegypti}

330 In total, 158/180 (88\%) (S4Table) of Ae. aegypti mosquito blood meal samples that amplified

331 successfully by PCR were of human origin, with a higher proportion in 2016 (92\%) than in 2017

$332(76 \%)\left(\chi_{1}^{2}=7.9, \mathrm{P}=0.005\right)$. None of the relatively few bloodfed mosquitoes from Goundry amplified

333 successfully in 2017 , but there was no significant difference in bloodfeeding rates between sites in

$3342016\left(\chi_{2}^{2}=0.2, P=0.90\right)$. Six bloodmeals contained blood from multiple hosts: five had human and

335 canine blood and one contained both canine and bovine blood (S4Table).

\section{Predictors of Aedes aegypti adult mosquito abundance}

337 Significant factors predicting Ae. aegypti adult abundance are shown in Table 3. Consistent with the 338 analyses presented above, locality (urban, peri-urban, rural) was a strong determinant, as was the

339 collection location (indoors $v s$. outdoors), with variation in the indoor:outdoor ratio between

340 localities shown by the significant interaction term. Whilst collections in Tabtenga and Goundry

341 were quite consistent between years, the number of Ae. aegypti collected in 1200 LG was much

342 lower in 2017 than 2016 (evident in the significant year and year x locality interaction terms).

343 However, it should be noted that the proportion of Ae. aegypti in the total mosquito catch was

344 similar, and actually slightly higher, in 1200 LG in 2017 as a result of a much lower abundance of

345 Cx. quinquefasciatus (Table 1). Collection month and rainfall also exerted significant effects with

346 reduced abundance in October, and a positive relationship with elevated previous over the past 14

347 days rainfall. Importantly, adult abundance was also predicted by the abundance of immature stages

348 from containers in or around the same household, with larval and pupal collections pooled due to

349 low pupal numbers. House type was retained in the minimal model, but explained little variation,

350 whilst other factors did not add to predictive value and were excluded from the final model. 
medRxiv preprint doi: https://doi.org/10.1101/2021.12.14.21267559; this version posted December 16, 2021. The copyright holder for this preprint (which was not certified by peer review) is the author/funder, who has granted medRxiv a license to display the preprint in perpetuity.

All rights reserved. No reuse allowed without permission.

351 Table 3: Aedes aegypti adult model glmm showing predictors beta estimates of effect size.

352 Confidence intervals, test statistic (z-value) and associated probability for the minimal model.

353 Significant predictors are highlighted in bold text, and non-significant terms, not included in the 354 model are listed on the bottom line.

\begin{tabular}{lcccc}
\hline Predictors & Beta & $95 \% \mathrm{CL}$ & $\mathrm{z}$-value & $\operatorname{Pr}(>|\mathrm{z}|)$ \\
\hline (Intercept) & $\mathbf{- 4 . 6 4}$ & $\mathbf{[ - 5 . 6 2 - - 3 . 6 6}]$ & $\mathbf{- 9 . 2 8}$ & $<\mathbf{0 . 0 0 1}$
\end{tabular}

355 Confidence intervals, test statistic (z-value) and associated probability for the minimal model.

356 Significant predictors are highlighted in bold text, and non-significant terms, not included in the 357 model are listed on the bottom line. 
Year [2016]

Locality [Rural]

Peri-urban

3.56

Urban

Location[indoors]

outdoors

Month [August]

October

September

14 days rainfall

House type [Mixed]

Modern

$-0.36$

$-0.42$

Traditional

Immature abundance

Year [2016]: Locality [Rural]

Year: Peri-urban

$-0.56$

Year: Urban

Locality [Rural]: Location [indoors]

0.99

4.58

$-0.91$

0.04

0.00

0.00
[-1.45--0.38] $\cdot \mathbf{3 . 3 4}$

$[-0.28-0.35] \quad 0.23$

[0.00-0.01] 2.28

$\mathbf{0 . 0 2 3}$

[0.5-1.48]

3.95

$<0.001$

[2.63-4.5] $\quad 7.45 \quad<0.001$

$[3.55-5.61] \quad 8.70 \quad<0.001$

$\left[\begin{array}{lll}{[1.31-2.22} & 7.67 & <0.001\end{array}\right.$

Peri-urban: outdoors

$-1.34$

$[-1.84--0.85] \quad-5.31$

$<0.001$

Urban: outdoors
[-0.73-0.01] -1.90

0.058

$[-1.23-0.39] \quad-1.01$

0.311

$[0.00-0.01] \quad 4.90 \quad<0.001$ $\left[\begin{array}{lll}-1.13-0.00] & -1.94 & 0.052\end{array}\right.$

$[-1.78--0.59] \quad-3.91<0.001$

$-0.28$

$[-0.8-0.24] \quad-1.04$

0.297

Non-significant terms were collection time(am/pm), House type, Children number, ITNs presence

ITNs number, Animals presence, animal number, locality*Year, Locality*Location 
medRxiv preprint doi: https://doi.org/10.1101/2021.12.14.21267559; this version posted December 16, 2021. The copyright holder for this

\section{Immature mosquito species abundance}

Aedes aegypti comprised over $85 \%$ of immature stages collected from habitats in the urban and peri-urban localities, 1200 LG and Tabtenga, but only 46.4\% in rural Goundry. In contrast, Aedes vittatus, which comprised less than $0.5 \%$ of the immatures collected in the two urban localities, amounted to $40.6 \%$ of the total in Goundry (S5Table). Aedes vittatus immatures were found mainly in water residues in the animal drinking troughs that were more common in Goundry than in the urban sites (S1Figure). Few immature Anopheles gambiae s.l. were collected in any site, as would be expected for a species that typically breeds in ground water pools rather than the containers sampled in this study.

Overall mosquito community composition was strongly influenced by collection location, which was consistent across the two sampling years, with significant difference between rural Goundry and the two urban sites (S1Figure).

\section{Habitats of immature stage Aedes aegypti}

Across all three localities, a total of 1,445 containers were inspected during the study of which 666 (46\%) contained Aedes aegypti larvae or pupae (Fig.3). Immatures were found in all container types inspected and although infestation rates of container types were significantly different across the

localities $\left(\chi^{2}=170 ; \mathrm{P}<<0.001\right.$; Figure 3$)$, there were some consistencies. Tires were among the most heavily infested in both urbanised localities, reaching rates of $31 \%$ and $32 \%$ in Tabtenga and 1200 LG respectively, but they were of minimal importance in Goundry, where infested domestic water storage drums (40\%) were the most heavily infested (Figure 3).

\section{Figure 3. Proportion of each container type positive for larvae (Figure 3A) and positive for} pupae Figure 3B).

Not all containers found to contain larvae may support development to the pupal stage and be 
medRxiv preprint doi: https://doi.org/10.1101/2021.12.14.21267559; this version posted December 16, 2021. The copyright holder for this preprint (which was not certified by peer review) is the author/funder, who has granted medRxiv a license to display the preprint in perpetuity. All rights reserved. No reuse allowed without permission.

regarded as productive for breeding. However for pupae, in urban and peri-urban sites, tires were highly productive habitats, containing $37 \%$ and $34 \%$ of all pupae in 1200 LG and Tabtenga respectively (Table 4; Figure 3).

Other highly productive containers included large water storage containers (drums, jars or barrels) from which, in Tabtenga, an area without piped water, $40 \%$ of pupae were found. In contrast, these large containers produced only $13 \%$ of pupae in 1200 LG, an area with piped water, and where instead, small containers including miscellaneous objects ( plastic and metallic boxes, terracotta pots, plastic shoes,.. ) were responsible for nearly $40 \%$ of the vector population.

Large water drums or barrels were also important in the semi-rural locality Goundry (30\%), where the most productive habitats were animal water troughs $(44 \%)$.

Table 4: Numbers of Aedes aegypti pupae found infesting containers and other potential habitats by locality, year of sampling and habitat type.

*Others includes ground water puddles, tree holes and plant pots of less than $3 L$. 
medRxiv preprint doi: https://doi.org/10.1101/2021.12.14.21267559; this version posted December 16, 2021. The copyright holder for this preprint (which was not certified by peer review) is the author/funder, who has granted medRxiv a license to display the preprint in perpetuity.

All rights reserved. No reuse allowed without permission.

\begin{tabular}{|c|c|c|c|c|c|c|c|c|}
\hline & \multicolumn{3}{|c|}{2016} & \multicolumn{3}{|c|}{2017} & \multirow[b]{2}{*}{ No. pupae } & \multirow[b]{2}{*}{$\begin{array}{c}\% \text { of total } \\
\text { pupae }\end{array}$} \\
\hline & Aug & Sep & Oct & Aug & Sep & Oct & & \\
\hline \multicolumn{9}{|c|}{1200 Logements } \\
\hline Tires & 277 & 322 & 17 & 219 & 118 & & 953 & 36.91 \\
\hline Large containers & 31 & 117 & 68 & 99 & 21 & & 336 & 13.01 \\
\hline Medium containers & 63 & 37 & 0 & 40 & 10 & & 150 & 5.81 \\
\hline Small containers & 255 & 470 & 14 & 249 & 31 & & 1019 & 39.47 \\
\hline Animal troughs & 16 & 19 & 0 & 6 & 32 & & 73 & 2.80 \\
\hline$*$ Others & 48 & 0 & 0 & 3 & 0 & & 51 & 2.00 \\
\hline total & 690 & 965 & 99 & 616 & 212 & 0 & 2582 & 100.00 \\
\hline \multicolumn{9}{|c|}{ Tabtenga } \\
\hline Tires & 404 & 373 & 3 & 281 & 365 & & 1426 & 33.98 \\
\hline Large containers & 154 & 362 & 0 & 365 & 250 & & 1131 & 26.95 \\
\hline Medium containers & 219 & 432 & 9 & 96 & 35 & & 791 & 18.85 \\
\hline Small containers & 91 & 377 & 39 & 139 & 45 & & 691 & 16.47 \\
\hline Animal troughs & 29 & 81 & 1 & 46 & 0 & & 157 & 3.75 \\
\hline *Others & 0 & 0 & 0 & 0 & 0 & & 0 & 0.00 \\
\hline total & 897 & 1625 & 52 & 927 & 695 & 0 & 4196 & 100 \\
\hline \multicolumn{9}{|c|}{ Goundry } \\
\hline Tires & 22 & 56 & 0 & 85 & 0 & 0 & 163 & 4.9 \\
\hline Large containers & 644 & 179 & 0 & 102 & 48 & 31 & 1004 & 30.24 \\
\hline Medium containers & 46 & 37 & 34 & 1 & 8 & 99 & 225 & 6.78 \\
\hline Small containers & 139 & 72 & 0 & 261 & 1 & 0 & 473 & 14.25 \\
\hline Animal troughs & 671 & 124 & 1 & 541 & 88 & 30 & 1455 & 43.83 \\
\hline *Others & 0 & 0 & 0 & 0 & 0 & 0 & 0 & 0.00 \\
\hline total & 1522 & 468 & 35 & 990 & 145 & 160 & 3320 & 100 \\
\hline
\end{tabular}

\section{Predictors of Aedes aegypti larval and pupal densities}

A generalised linear model fitted to the number of Aedes aegypti larvae collected per breeding site showed an effect of year (2017 collections > 2016 collections) and significant differences between 
medRxiv preprint doi: https://doi.org/10.1101/2021.12.14.21267559; this version posted December 16, 2021. The copyright holder for this

localities, which were consistent across years, with both the urban and peri-urban localities having much higher densities than the rural site, Goundry (S6Table). Container type influenced larval density with highest larval densities found in tires. Higher water levels in containers were also associated with higher larval density and highest larval densities occurred in September compared to August and October, though all were similar. Factors such as cumulative rainfall totals measured over 2 or 7 days, temperature, container purpose, number of residents, and numbers of adult mosquitoes collected had no significant associations with larval density.

Pupal density did not differ significantly between years, and was higher only in Tabtenga than Goundry, with urban 1200 LG not significantly different (S7Table). Container type influenced pupal density, but in contrast to larvae, tires were not significantly more productive, with only animal drinking troughs significantly higher than the reference category. Container utility was important as pupal density was reduced by $43 \%$ in functional containers compared with nonfunctional/discarded containers Pupal density was also negatively associated with mean temperature and was also positively associated with the number of adult mosquitoes collected in the same house.

\section{Stegomyia and pupae/person indices}

The Stegomyia indices are summarized in Figure 2, and show that the WHO thresholds were exceeded for all stegomyia indices in Goundry. In the peri-urban locality of Tabtenga, the container and pupal indices exceeded the WHO thresholds, but the Breteau and House Indices, were less informative in 2017.

Figure 2. Breteau, container and houses indices (and $95 \%$ confidence intervals) and the number of pupae per person (PPI) (and 95\% confidence limits) per year and per locality. The red line indicates the WHO thresholds that are set at 50, 20 and 35 respectively for BI, CI and HI. The PPI threshold is estimated based on an initial seroprevalence of $33 \%$ and an average temperature of $28 \mathrm{C}$ and for an increase of $10 \%$ of the seroprevalence [38] 
medRxiv preprint doi: https://doi.org/10.1101/2021.12.14.21267559; this version posted December 16, 2021. The copyright holder for this

\section{Spatial distribution of immature stages and adult collections}

Mapping of immature and adult densities showed some, albeit very imperfect overlaps between the different life stages in each locality (Figure 4). Niche overlap analysis showed that approaching half of the distribution of adults and immatures overlapped (index $=0.44$ ). Whilst this varied between locations, with a lower index value in Goundry (index=0.29) compared to peri-urban (index $=0.56$ ) and urban (index $=0.55$ ) the overall spatial correlation of the distribution is consistently high (Pearson correlation $=0.74)$ regardless of the location.

Figure 4: Densities map of Aedes aegypti adult (top) and larval (down) densities per house in Goundry (left), Tabtenga (middle) and 1200LG (right).

\section{Discussion}

The objective of this study was to generate detailed baseline data on the biology and behaviour of Ae. aegypti in Burkina Faso, contributing to the essential evidence-base for developing dengue prevention and outbreak plans. The key findings indicate that the arbovirus vector Ae. aegvpti is common throughout Ouagadougou, and most abundant in the highly populated central areas where infestation rates reach $78 \%$ of dwellings. Adult females are predominantly anthropophagic and also highly exophilic, though feeding more indoors than exophily rates would suggest. Females also appear to oviposit in all container types, both in use or discarded. The key container habitats, those harboring the highest numbers of pupae, and from which the greatest numbers of adults emerge, were discarded car tires, large domestic water containers (drums and barrels) and small containers (including discarded vessels). Aedes aegypti were caught in both mornings and evenings, consistent with their expected pattern of diurnal activity, but it is unclear to what extent they may be also nocturnally active. 
medRxiv preprint doi: https://doi.org/10.1101/2021.12.14.21267559; this version posted December 16, 2021. The copyright holder for this

The profile in the rural outskirts of the city appears to be quite different. Here there was a greater diversity of mosquito species, the most common of which were Anopheles gambiae and Culex quinquefasciatus, and Aedes vittatus. The most productive containers in Goundry for both Ae. aegypti and Ae. vittatus were animal drinking water troughs. The most significant mosquito-borne disease risk here is malaria, though the presence of significant numbers of Ae. vittatus is of note pending more insight into any vectorial role it might have in this area. Aedes vittatus occurs throughout Africa, tropical Asia, and southern Europe and was recently discovered in the Caribbean [56]. Although its vectorial capacity is not known, it occurs in both sylvatic and peridomestic environments, feeds on humans and is involved in the maintenance and transmission of yellow fever, Zika, chikungunya, and dengue [57].

However, in the higher density urban and peri-urban areas within Ouagadougou, Ae. aegypti was the only arbovirus vector of concern and was, almost certainly, the only active vector during the dengue outbreaks of 2016 and 2017. The likelihood of future outbreaks of dengue and other arboviruses transmitted by Ae. aegypti is high and a programme to prevent, limit or respond to dengue outbreaks must now be considered a public health priority to protect urban populations.

Ideally, dengue vector control programmes should involve two strategies, the first for vector population suppression, a year-round or pre wet season programme to maintain a low vector population, and the second strategy for responding rapidly to disease outbreaks[58]. Suppressing vector populations typically employs sustainable appropriate methods targeting the immature stage habitats. Diligent sustained action by community groups can have major impacts, and be effective in both outbreak prevention and response, even in the absence of insecticides [59-62]. This requires regular waste disposal for elimination of discarded materials, containers with no function and general garbage. Water barrels, tanks or jars or any other functional or in-use containers should have tightly fitting lids, while empty bottles and buckets should be stored inverted. Targeting the highly productive container types, i.e., those that produce over $70 \%$ of all Ae. aegypti pupae, is recommended by WHO [28]. Although more work is required to identify all key container types in 
medRxiv preprint doi: https://doi.org/10.1101/2021.12.14.21267559; this version posted December 16, 2021. The copyright holder for this

Ouagadougou in dry and wet seasons, it is already clear that car tires are an important habitat responsible for producing over $30 \%$ of adult vectors in the wet season, with drums and barrels used for water storage potentially increasing in importance in the dry season. Tires are a unique and easily recognised waste item, apparently with no monetary value and a successful campaign to remove them would be a useful milestone (while raising the difficult question of what to do with the tires collected). Before decisions are reached however, the survey should be repeated in the dry season, when the vector population will be at its lowest and most vulnerable level and the most productive container types might be different.

Larviciding can also be used for larval reduction using temephos, an organophosphate and two biological insecticides Bti and pyriproxyfen. Preliminary data shows organophosphates are effective against Aedes aegypti larvae in Burkina [63], but data on efficacy of Bti and pyriproxyfen area awaited. Although the identification of key containers for pupal productivity may reduce the challenge, the diversity and the number of breeding containers will compromise larviciding as a stand-alone method for dengue control in Burkina Faso.

Aedes aegypti adults can be prevented from entering buildings by screens fitted to windows, which do not necessarily need to be insecticide-treated to be effective $[64,65]$. Indoor resting can be controlled by targeted indoor residual spraying (TIRS), where only the lower half of the walls are treated with insecticide or by using hand-held aerosol cans to spray known resting indoor sites [6668]. Clearly, further work is required to fully elucidate resting preferences, a critical question for planning control, and we recommend that the efficacy of IRS against Ae. aegypti in Africa is evaluated experimentally as a priority even as we recognise that exophilic behaviour may recommend additional control methods. The high levels of exophily recorded in this study (Fig. 1) and the high exophagy levels recorded in Banfora/Ouagadougou? (Toé, et al, unpublished) raise the question of whether IRS is an appropriate method for control of Ae. aegypti in west Africa. Of the two Ae. aegypti forms known to occur in Burkina Faso, only Ae. aegypti aegypti (Aaa) exhibits synanthropic behaviour, including endophily and endophagy [69]. Endophilic behaviour has been 
medRxiv preprint doi: https://doi.org/10.1101/2021.12.14.21267559; this version posted December 16, 2021. The copyright holder for this

documented in Ae. aegypti since the earliest research [70] and is a common feature of populations worldwide [71,72]. Throughout its range in Africa, substantial or even preferential outdoor activity by Aaa is not unusual, and has been reported from Ghana [73], Senegal [40] and Kenya [74]. Exophilic or endophilic preferences may not be exclusively one or the other, and many Ae. aegypti populations exhibit both. For example, in Kenya, Teesdale recorded details of Ae. aegypti daily cycles of movement in and out of houses [74], while a study in Mexico recorded indoor and outdoor biting and resting, with exophagy the more common [75]. Despite this, the studies demonstrating the impact of TIRS (Targeted Indoors Residual Spray) on Ae. aegypti were also performed in Mexico. In Burkina Faso, we found a significantly higher than expected proportion of bloodfed females resting indoors which suggests that exophily may not dominate the entire adult stage and that adult females are likely endophagic or come indoors at some stage after bloodfeeding.

The majority of bloodmeals were identified as human in origin, with the remainder from dogs and only one sample from cattle (Table S4). Notably, only 6-7\% of bloodmeals were non-human in samples from the urban localities, but $28 \%$ of bloodmeals in the semi-rural site were from dogs. Aedes aegypti exists in two forms in Africa, Ae. aegypti aegypti (Aaa) inhabit domestic environments, breed in artificial containers, and are highly anthropophagic, and Ae. aegypti formosus, (Aaf) the forest form which is zoophilic [76]. We found that the abdominal scaling patterns used to discriminate the forms $[42,77]$ were not useful for discriminating forms among our samples from Ouagadougou (unpublished results). Genetic studies have shown that the Ouagadougou population is an interbred population mixture of Aaa and Aaf, expressing intermediate animal and human preferences [4]. The results presented here point towards an urban population displaying predominantly Aaa behaviour and a rural population that is still anthropophilic but with a far greater likelihood of zoophagy [4]. Clarification of host preference is an important element of a mosquito population's vectorial capacity but doing so will require a larger sample size and additional studies to gain more insight. We recommend that this be prioritised together with the studies on indoor/outdoor feeding and resting preferences. 
medRxiv preprint doi: https://doi.org/10.1101/2021.12.14.21267559; this version posted December 16, 2021. The copyright holder for this

We found higher densities of adult Ae. aegypti in urban and peri-urban localities of $1200 \mathrm{LG}$ and Tabtenga, compared to Goundry, the rural locality. Adults rested mainly outdoors in all sites, feeding preferentially on humans with rare canine or bovine bloodmeals and their densities were affected by month and the year of collection, the locality, the indoors/outdoors location and at a lesser extent by the immature stage abundance and the cumulative rain of 14 previous days.

Ae. aegypti was the main Aedes species collected at all developmental stages, in all localities, in both years. Ae. aegypti adults and larvae densities followed a negative gradient from urban to rural localities. Urbanisation has been identified as the main driver of Ae. aegypti proliferation in Africa $[4,78]$, and other environmental changes resulting from human activities promote higher abundance and lower species diversity; lower abundance and higher species diversity are more typical of natural environments and ecosystems [79]. In our study, the diversity of all culicines was greater in the rural site, Goundry, than in the urban and peri-urban localities. Goundry is predominantly agricultural land at the edge of the bush, with trees and scrubland beyond. Aedes vittatus was common here only, preferring animal drinking troughs as larval habitats. Also found only at Goundry, the predatory larvae of Lutzia tigripes shared some habitats with a prey species, Ae. aegypti and may have contributed to the lower densities of Ae. aegypti in Goundry compared to Tabtenga and 1200 LG. Important vector mosquitoes included Culex quinquefasciatus which was common here though not as abundant as at the other localities, and Anopheles gambiae s.1., which was common.

Multiple containers types were found to contain larvae in urban and peri-urban sites, with tires the most common. The typology of containers may vary according to the locality. Drums and barrels that are used for water storage, are more abundant in the rural and peri-urban localities of Goundry and Tabtenga where piped water is either absent or rare. Studies in central and East Africa have reported tires as the main breeding sites for Aedes mosquitoes [78,80,81]. In Indonesia, the most abundant breeding containers were bird watering dishes, tires had the highest frequency of positivity, while large open tanks storing water (known as Bak Mandi) were the most productive 
medRxiv preprint doi: https://doi.org/10.1101/2021.12.14.21267559; this version posted December 16, 2021. The copyright holder for this

containers [82]. The relative importance of any container is highly context-specific and any container's contribution to the vector population can easily be underestimated $[83,84]$.

Breeding site characteristics that affect immature stages abundance and adult life history traits include among others, dissolved oxygen, water temperature, $\mathrm{pH}$, conductivity and salinity [85]. Characteristics such as dissolved solids, ammonia, nitrate, and organic matter vary significantly between urban and rural containers, which might explain some urban-rural differences in breeding of Ae. aegypti [86]. We examined a limited number of breeding sites characteristics and environmental variables and found that container types and water levels within, can increase larval density while containers that are in use, or classed as useful, decrease pupal density. Cumulative rainfall of the previous 14 days and mean temperature affect adult and pupal densities respectively. Investigations in Iquitos used a generalised additive model to highlight the important contribution to Ae. aegypti adult density of weather-related covariates including temperature, rainfall and wind [87]. Though our study did not consider other covariates related to breeding sites, the density of immature stages was the strongest covariate in the model contributing to adult density.

Immature stages as well as adult densities were more affected by the month of collection with September the peak month of higher densities, compared to August and October. Although immature stages contributed to adult density, only pupal density was affected by adult abundance. The spatial distribution of adult and immature stage hotspots showed consistent overlapping and limited dispersal of adults from the immature stage location as shown in Lacon et al [88] and in Bonnet et al. [89] who showed that removing breeding sites had a direct impact on proliferation of adults.

As the Stegomyia indices have not previously been reported from Burkina Faso, we do not know what levels are typical during a non-outbreak period. During our study, the Stegomyia index values exceeded the WHO threshold for dengue risk in the rural locality of Goundry; paradoxically as this was the site where the lowest numbers of adult Aedes aegypti were recorded, and far from the central area of Ouagadougou where mainly urban and cases were known to be concentrated. In 
medRxiv preprint doi: https://doi.org/10.1101/2021.12.14.21267559; this version posted December 16, 2021. The copyright holder for this

addition, there is no evidence that any quantifiable associations exist between these indices of vector immature stages abundance and dengue transmission, and the thresholds have little value for prediction of dengue outbreaks [90,91]. Instead, research has moved to investigating whether numbers of adult female Ae. aegypti numbers can provide more accurate and reliable alerts [91]. In this study the number of total adults collected was highly correlated with the number of fed females collected and their density models shared the same explanatory variables. In contrast to Stegomyia indices, which are based on immature stage numbers, estimating the total number of adult Ae. aegypti can be more informative but remains challenging, with precision depending of the sampling methods and sampling efforts [37]. We found a pattern of similarities between spatial distribution of adults and immature stages with hotspots overlapping in the urban sites, at least. More consistent indices are needed, to take into account Ae. aegypti resting and blood feeding behaviour, and the typology of breeding sites that are productive for pupae, yet potentially specific to the locality. Associating dengue active case detection in the community with holistic collection of Ae. aegypti bionomics collection could allow more consistent inferences to be made.

Without vaccines for three of the four arboviruses transmitted by Ae. aegypti, Burkina Faso, like every other country, must rely on existing vector control tools as it plans its dengue control programme. Burkina Faso has endured a heavy malaria burden for decades during which time it built considerable capacity in vector control of Anopheles sp. [92]. It is now attempting the same for Ae. aegypti, a mosquito with very different biology and behavior to malaria vectors and consequently, requiring a different approach for control.

Since so many larval habitats are essentially waste materials, clean-up campaigns accompanied by appropriate education and information programs are essential and, in fact have already been established in Ouagadougou [89]. However, selection and likelihood of success of even the most appropriate interventions should be based on more than method of delivery and insecticide susceptibility of the target population. Gaining access to a home to deliver indoor treatments may be prevented if occupants are out working or studying elsewhere. If this type of 'refusal' occurs at 
medRxiv preprint doi: https://doi.org/10.1101/2021.12.14.21267559; this version posted December 16, 2021. The copyright holder for this

a high rate, achieving satisfactory coverage would be compromised. A house's structure, shape or construction materials can determine its suitability for fitted interventions such as window screens. Despite evidence that it is rarely effective [93], fogging or space-spraying outdoors is a popular response to Ae. aegypti borne arbovirus outbreaks worldwide. A high-profile activity, spacespraying is routine for many local authorities worldwide, the expected response to an outbreak although it can impact on transmission only if it is applied at frequent intervals and sustained for many weeks $[87,88]$. The exophilic character of the Aedes aegypti populations in Ouagadougou may support this method but as the same vector populations also show high resistance to pyrethroid insecticides [63,94], selection of insecticide should be based on up to date insecticide susceptibility testing together with safety considerations.

Pending the clarification of the vector population's behavioral preferences in the key areas described above, a program for vector control of dengue in Burkina Faso should be possible despite the limited range of interventions available. The Wolbachia method offers unprecedented impacts [95]but a date when it might be considered affordable and biologically suitable for use in Africa, may be many years away. Until then, or until a time when another equally effective intervention method is available, existing methods should be sufficient to at least reduce the frequency and mitigate the impact of outbreaks.

\section{Conclusion}

This report describes the Ae. aegypti population before and during dengue outbreaks in Ouagadougou. Although additional dry season data are required, the study provides the most complete contemporary description of an Ae. aegypti population in West Africa and provides sufficient evidence to develop programs for prevention and control of outbreaks. Recognizing that many of the breeding, bloodfeeding and resting site preferences reported here are likely to occur in vector populations elsewhere in West Africa, we cannot overly stress the importance of undertaking 
medRxiv preprint doi: https://doi.org/10.1101/2021.12.14.21267559; this version posted December 16, 2021. The copyright holder for this

further research to characterize those habits in additional vector populations. Together with insecticide resistance status, these preferences determine the success of any control method and where possible, characterization should be based on evidence rather than assumption, especially if based on contexts outside Africa.

This study has done little to alter the view that the Stegomyia indices have limited epidemiological value or that they are likely to be more relevant in Africa than they have been elsewhere.

Identifying alternatives however remains elusive. While there are similarities between immature stage and adult densities and similarities in spatial distribution, determining how these might be applied or how they could be combined with additional epidemiological parameters to generate more accurate indices reflecting the transmission potential of Ae. aegypti and disease risk remains a challenge.

All of these topics fit well within a regional approach to arbovirus control. Networks mapping Ae. aegypti key behaviors across the African continent, together with accurate indices of arbovirus risk, insecticide susceptibility/resistance status and key epidemiological parameters would be an important step towards an effective regional/ global control strategy. We suspect that such an initiative would have broad support.

\section{List of Tables and Figure Legends}

Figure 1. Indoor and outdoor resting behavior of adult female Ae. aegypti in domestic housing in Ouagadougou. Geometric means and $95 \%$ confidence limits of numbers of Ae. aegypti adults collected indoors and outdoors per house, in the three localities in 2016 and 2017.

Figure 2. Breteau, container and houses indices (and their $95 \%$ confidence) and the number of pupae per person (PPI) (and 95\% confidence limits) per year and per locality. The red line indicates the WHO thresholds that are set at 50,20 and 35 respectively for BI, CI and HI. The PPI 
medRxiv preprint doi: https://doi.org/10.1101/2021.12.14.21267559; this version posted December 16, 2021. The copyright holder for this

threshold is estimated based on an initial seroprevalence of $33 \%$ and an average temperature of $28 \mathrm{C}$ and for an increase of $10 \%$ of the seroprevalence [37]

Figure 3. Proportion of each container type positive for larvae (Figure 3A) and positive for pupae Figure 3B).

Figure 4: Densities map of Aedes aegypti adult (top) and larval (down) densities per house in Goundry (left), Tabtenga (middle) and 1200LG (right).

\section{Supporting Information Legends}

S1Table. Household characteristics and demography in the three localities during the two years of collection, 2016 and 2017.

S2Table. Average number per house, the $95 \%$ confidence limits [in brackets] and the total number of mosquitoes (in parenthesis) of Aedes aegypti mosquitoes collected in the study localities in 2016 and 2017

S3Table. Average number of mosquitoes per house, the $95 \%$ confidence limits [in brackets] and the total number (in parenthesis) collected in the morning (am) and in the afternoon (pm) of the three main species of mosquito collected in the study localities in 2016 and 2017.

S4Table. Number of bloodfed, number of PCR-tested, and bloodmeal sources of Aedes aegypti mosquitoes per locality and per year.

S5Table. Relative abundance of mosquito species collected as larvae and pupae during routine house sampling in each locality and year.

S6Table. Generalised linear mixed model of Aedes aegypti larval density.

S7Table. Generalised linear mixed model of Aedes aegypti pupal density.

S1Figure. Mosquito community diversity in immature collections in each location and year. 
medRxiv preprint doi: https://doi.org/10.1101/2021.12.14.21267559; this version posted December 16, 2021. The copyright holder for this preprint (which was not certified by peer review) is the author/funder, who has granted medRxiv a license to display the preprint in perpetuity. All rights reserved. No reuse allowed without permission. 
medRxiv preprint doi: https://doi.org/10.1101/2021.12.14.21267559; this version posted December 16, 2021. The copyright holder for this preprint (which was not certified by peer review) is the author/funder, who has granted medRxiv a license to display the preprint in perpetuity. All rights reserved. No reuse allowed without permission.

\section{Acknowledgments}

The authors thank members and leaders of communities in the localities of 1200 Logements,

Tabtenga and Goundry for their permission to perform the study and their cooperation throughout.

\section{Author Contributions}

Conceptualization: Athanase Badolo, David Weetman, Philip J. McCall.

Data curation: Athanase Badolo, Aboubacar Sombié.

Formal analysis: Athanase Badolo, Mafalda Vienna, David Weetman, Philip J. McCall.

Funding acquisition: Athanase Badolo, David Weetman, Philip J. McCall.

Investigation: Athanase Badolo, Aboubacar Sombié, David Weetman, Philip J. McCall.

Methodology: Athanase Badolo, David Weetman, Philip J. McCall.

Project administration: Athanase Badolo, Antoine Sanon.

Resources: Athanase Badolo, Antoine Sanon, Hirotaka Kanuka.

Software: Athanase Badolo, Mafalda Vienna.

Supervision: David Weetman, Philip J. McCall.

Validation: Athanase Badolo, Mafalda Vienna, David Weetman, Philip J. McCall.

Visualization: Athanase Badolo, Mafalda Vienna, David Weetman, Philip J. McCall.

Writing - original draft: Athanase Badolo.

Writing - review \& editing: Mafalda Vienna, David Weetman, Philip J. McCall. 
medRxiv preprint doi: https://doi.org/10.1101/2021.12.14.21267559; this version posted December 16, 2021. The copyright holder for this preprint (which was not certified by peer review) is the author/funder, who has granted medRxiv a license to display the preprint in perpetuity. All rights reserved. No reuse allowed without permission.

\section{References}

1. Bhatt S, Gething PW, Brady OJ, Messina JP, Farlow AW, Moyes CL, et al. The global distribution and burden of dengue. Nature. 2013;496: 504-7. doi:10.1038/nature12060

2. Norrby R. Outlook for a dengue vaccine [Internet]. Clinical Microbiology and Infection. 2014. pp. 92-94. doi:10.1111/1469-0691.12442

3. Messina JP, Brady OJ, Golding N, Kraemer MUG, Wint GRW, Ray SE, et al. The current and future global distribution and population at risk of dengue. Nat Microbiol. Nature Publishing Group; 2019;4: 1508-1515. doi:10.1038/s41564-019-0476-8

4. Rose NH, Sylla M, Badolo A, Lutomiah J, Ayala D, Aribodor OB, et al. Climate and Urbanization Drive Mosquito Preference for Humans. Curr Biol. 2020;30: 3570-3579.e6. doi:10.1016/j.cub.2020.06.092

5. Powell JR, Tabachnick WJ. History of domestication and spread of Aedes aegypti--a review. Memórias do Instituto Oswaldo Cruz. 2013. doi:10.1590/0074-0276130395

6. Shragai T, Tesla B, Murdock C, Harrington LC. Zika and chikungunya: mosquito-borne viruses in a changing world [Internet]. Annals of the New York Academy of Sciences. Blackwell Publishing Inc.; 2017. pp. 61-77. doi:10.1111/nyas.13306

7. Balogun EO, Nok AJ, Kita K. Global warming and the possible globalization of vector-borne diseases: A call for increased awareness and action. Tropical Medicine and Health. 2016. doi:10.1186/s41182-016-0039-0

8. Iwamura T, Guzman-Holst A, Murray KA. Accelerating invasion potential of disease vector Aedes aegypti under climate change. Nat Commun. Nature Research; 2020;11. doi:10.1038/s41467-020-16010-4

9. UN. World Urbanization Prospects - Population Division - United Nations [Internet]. United Nations. 2019. Available: https://population.un.org/wup/ 
medRxiv preprint doi: https://doi.org/10.1101/2021.12.14.21267559; this version posted December 16, 2021. The copyright holder for this

10. Saghir J, Santoro J. Urbanization in Sub-Saharan Africa. Meeting Challenges by Bridging Stakeholders. Cent Strateg Int Stud. 2018; 7. Available:

https://www.csis.org/analysis/urbanization-sub-saharan-africa

11. Abdulwahab Alhakimi H, Gadalla Mohamed O, Salah Eldin Khogaly H, Ahmad Omar Arafa K, Amen Ahmed W. Epidemiological, Clinical and Entomological Characteristics of Yellow Fever Outbreak in Darfur 2012. AIMS Public Heal. American Institute of Mathematical Sciences (AIMS); 2015;2: 132-141. doi:10.3934/publichealth.2015.1.132

12. Woodall JP, Yuill TM. Why is the yellow fever outbreak in Angola a 'threat to the entire world'? International Journal of Infectious Diseases. Elsevier B.V.; 2016. pp. 96-97. doi:10.1016/j.ijid.2016.05.001

13. Kaul RB, Evans M V., Murdock CC, Drake JM. Spatio-temporal spillover risk of yellow fever in Brazil. Parasites and Vectors. BioMed Central Ltd.; 2018;11. doi:10.1186/s13071018-3063-6

14. Ingelbeen B, Weregemere NA, Noel H, Tshapenda GP, Mossoko M, Nsio J, et al. Urban yellow fever outbreak-Democratic Republic of the Congo, 2016: Towards more rapid case detection. PLoS Negl Trop Dis. Public Library of Science; 2018;12.

doi:10.1371/journal.pntd.0007029

15. Markoff L. Yellow Fever Outbreak in Sudan. N Engl J Med. New England Journal of Medicine (NEJM/MMS); 2013;368: 689-691. doi:10.1056/nejmp1300772

16. Kwagonza L, Masiira B, Kyobe-Bosa H, Kadobera D, Atuheire EB, Lubwama B, et al. Outbreak of yellow fever in central and southwestern Uganda, February-may 2016. BMC Infect Dis. BioMed Central Ltd.; 2018;18. doi:10.1186/s12879-018-3440-y

17. Jean K, Raad H, Gaythorpe KAM, Hamlet A, Mueller JE, Hogan D, et al. Assessing the impact of preventive mass vaccination campaigns on yellow fever outbreaks in Africa $\square$ : a population-level self-controlled case-series study. Grais RF, editor. medRxiv. PLoS Med; 
medRxiv preprint doi: https://doi.org/10.1101/2021.12.14.21267559; this version posted December 16, 2021. The copyright holder for this

2020;18: 2020.07.09.20147355. doi:10.1371/journal.pmed.1003523

18. Lucey D, Gostin LO. A yellow fever epidemic a new global health emergency? [Internet]. JAMA - Journal of the American Medical Association. American Medical Association; 2016. pp. 2661-2662. doi:10.1001/jama.2016.6606

19. Konongoi SL, Nyunja A, Ofula V, Owaka S, Koka H, Koskei E, et al. Human and entomologic investigations of chikungunya outbreak in Mandera, Northeastern Kenya, 2016. PLoS One. Public Library of Science; 2018;13. doi:10.1371/journal.pone.0205058

20. Russo G, Subissi L, Rezza G. Chikungunya fever in Africa: a systematic review. Pathogens and Global Health. Taylor and Francis Ltd.; 2020. pp. 136-144.

doi:10.1080/20477724.2020.1748965

21. Humphrey JM, Cleton NB, Reusken CBEM, Glesby MJ, Koopmans MPG, Abu-Raddad LJ. Urban Chikungunya in the Middle East and North Africa: A systematic review. PLoS Negl Trop Dis. Public Library of Science; 2017;11. doi:10.1371/journal.pntd.0005707

22. Gudo ES, Pinto G, Vene S, Mandlaze A, Muianga AF, Cliff J, et al. Serological Evidence of Chikungunya Virus among Acute Febrile Patients in Southern Mozambique. PLoS Negl Trop Dis. Public Library of Science; 2015;9. doi:10.1371/journal.pntd.0004146

23. Lourenco J, Monteiro M de L, Valdez T, Rodrigues JM, Pybus O, Faria NR, et al. Zika virus outbreak in Cabo Verde Islands, West Africa: early epidemiological findings. bioRxiv. 2017; doi:10.1101/198952

24. Puntasecca CJ, King CH, LaBeaud AD. Measuring the global burden of chikungunya and Zika viruses: A systematic review. Mostafa A, editor. PLoS Negl Trop Dis. Public Library of Science; 2021;15: e0009055. doi:10.1371/journal.pntd.0009055

25. Stoler J, al Dashti R, Anto F, Fobil JN, Awandare GA. Deconstructing "malaria": West Africa as the next front for dengue fever surveillance and control. Acta Trop. 2014;134: 5865. doi:10.1016/j.actatropica.2014.02.017 
medRxiv preprint doi: https://doi.org/10.1101/2021.12.14.21267559; this version posted December 16, 2021. The copyright holder for this

26. Arunachalam N, Tana S, Espino F, Kittayapong P, Abeyewickreme W, Wai KT, et al. Ecobio-social determinants of dengue vector breeding: A multicountry study in urban and periurban Asia. Bull World Health Organ. 2010;88: 173-184. doi:10.2471/BLT.09.067892

27. Quintero J, Brochero H, Manrique-Saide P, Barrera-Pérez M, Basso C, Romero S, et al. Ecological, biological and social dimensions of dengue vector breeding in five urban settings of Latin America: a multi-country study. BMC Infect Dis. 2014;14: 38. doi:10.1186/14712334-14-38

28. Manrique-Saide P, Che-Mendoza, AzaelRizzo N, Pilger D, Lenhart A, Kroeger A, Arana B. Operational guide for assessing the productivity of Aedes aegypti breeding sites. World Heal Organ. 2011;

29. Bowman LR, Tejeda GS, Coelho GE, Sulaiman LH, Gill BS, McCall PJ, et al. Alarm variables for dengue outbreaks: A multi-centre study in Asia and Latin America. PLoS One. 2016;11: 1-23. doi:10.1371/journal.pone.0157971

30. Weetman D, Kamgang B, Badolo A, Moyes CL, Shearer FM, Coulibaly M, et al. Aedes mosquitoes and Aedes-borne arboviruses in Africa: Current and future threats. Int J Environ Res Public Health. 2018;15. doi:10.3390/ijerph15020220

31. Aubry F, Jacobs S, Darmuzey M, Lequime S, Delang L, Fontaine A, et al. Recent African strains of Zika virus display higher transmissibility and fetal pathogenicity than Asian strains. Nat Commun. Springer Science and Business Media LLC; 2021;12. doi:10.1038/s41467$021-21199-\mathrm{z}$

32. Aubry F, Dabo S, Manet C, Filipović I, Rose NH, Miot EF, et al. Enhanced Zika virus susceptibility of globally invasive Aedes aegypti populations. Science (80- ). American Association for the Advancement of Science; 2020;370: 991-996. doi:10.1126/science.abd3663

33. WHO. WHO | Dengue Fever - Burkina Faso. WHO. World Health Organization; 2016; 
medRxiv preprint doi: https://doi.org/10.1101/2021.12.14.21267559; this version posted December 16, 2021. The copyright holder for this

Available: https://www.who.int/csr/don/18-november-2016-dengue-burkina-faso/en/

34. WHO. WHO | Dengue fever - Burkina Faso. WHO. World Health Organization; 2017;

Available: https:/www.who.int/csr/don/6-november-2017-dengue-burkina-faso/en/

35. Tarnagda Z, Congo M, Sagna T, Ouédraogo C, Nikiéma V, Cissé A, et al. Outbreak of dengue fever in Ouagadougou , Burkina Faso, 2013. Int J Microbiol Immunol Res. 2014;2:

$101-108$.

36. Tarnagda Z, Cissé A, Bicaba BW, Diagbouga S, Sagna T, Ilboudo AK, et al. Dengue fever in Burkina faso, 2016. Emerging Infectious Diseases. 2018. doi:10.3201/eid2401.170973

37. Focks DA. A review of entomological sampling methods and indicators for dengue vectors. Geneva WHO. 2003; Available: http://searo.who.int/LinkFiles/Dengue_book_review_1.pdf

38. Focks DA, Haile DG, Daniels E, Mount GA. Dynamic life table model for Aedes aegypti (Diptera: Culcidae): Analysis of the literature and model development. J Med Entomol. Entomological Society of America; 1993;30: 1003-1017. doi:10.1093/jmedent/30.6.1003

39. Vazquez-Prokopec GM, Galvin WA, Kelly R, Kitron U. A New, Cost-Effective, BatteryPowered Aspirator for Adult Mosquito Collections. J Med Entomol. 2009; doi:10.1603/033.046.0602

40. Diallo D, Diallo M. Resting behavior of Aedes aegypti in southeastern Senegal. Parasites and Vectors. 2020;13. doi:10.1186/s13071-020-04223-x

41. Koyoc-Cardeña E, Medina-Barreiro A, Cohuo-Rodríguez A, Pavía-Ruz N, Lenhart A, Ayora-Talavera G, et al. Estimating absolute indoor density of Aedes aegypti using removal sampling. Parasites and Vectors. BioMed Central Ltd.; 2019;12. doi:10.1186/s13071-019$3503-y$

42. Mattingly PF. Taxonomy of Aedes aegypti and related species. Bull World Health Organ. 1967;36: 552-554. 
medRxiv preprint doi: https://doi.org/10.1101/2021.12.14.21267559; this version posted December 16, 2021. The copyright holder for this

43. McClelland GA. A preliminary study of the genetics of abdominal colour variations in Aëdes aegypti (L.) (Diptera, Culicidae). Ann Trop Med Parasit. Liverpool; 1960;54: 305-320 . Available:

http://www.cabdirect.org/abstracts/19621000081.html;jsessionid=BED410C009EB788A6B6 8C3405E724465

44. Mattingly PF, Bruce-Chwatt LJ. Morphology and bionomics of Aëdes (Stegomyia) pseudoafricanus Chwatt (Diptera, Culicidae), with some notes on the distribution of the subgenus stegomyia in Africa. Ann Trop Med Parasitol. 1954;48: 183-93. Available: http://www.ncbi.nlm.nih.gov/pubmed/13189334

45. Moore M, Sylla M, Goss L, Burugu MW, Sang R, Kamau LW, et al. Dual African Origins of Global Aedes aegypti s.l. Populations Revealed by Mitochondrial DNA. PLoS Negl Trop Dis. 2013;7. doi:10.1371/journal.pntd.0002175

46. Edwards FW. Mosquitoes of the ethiopian region. III. Culicine adults and pupae. London: British. Museum (Nat. Hist.); 1941.

47. Gillies MT, Coetzee M. A supplement to the Anophelinae of Africa south of the Sahara (Afrotropical Region). Johannesburg: South African Institute for Medical Research; 1987.

48. Diagne N, Fontenille D, Konate L, Faye O, Lamizana M, Legros F, et al. Anopheles of Senegal, an annotated and illustrated list. Bull Soc Pathol Exot. 1994;87: 267-77.

49. Santolamazza F, Mancini E, Simard F, Qi Y, Tu Z, Della Torre A. Insertion polymorphisms of SINE200 retrotransposons within speciation islands of Anopheles gambiae molecular forms. Malar J. Malar J; 2008;7. doi:10.1186/1475-2875-7-163

50. Kent RJ, Norris DE. Identification of mammalian blood meals in mosquitoes by a multiplexed polymerase chain reaction targeting cytochrome B. Am J Trop Med Hyg. 2005;73: 336-342.

51. Hartig F. DHARMa: Residual Diagnostics for Hierarchical (Multi-Level / Mixed) Regression 
medRxiv preprint doi: https://doi.org/10.1101/2021.12.14.21267559; this version posted December 16, 2021. The copyright holder for this

Models. R Packag version 020. 2018; https://CRAN.R-project.org/package=DHARMa. Available: http://cran.nexr.com/web/packages/DHARMa/vignettes/DHARMa.html

52. Ou B, Zhao X, Wang M. Power of Moran's I Test for Spatial Dependence in Panel Data Models with Time Varying Spatial Weights Matrices. J Syst Sci Inf. Journal of Systems Science and Information (JSSI); 2017;3: 463-471. doi:10.1515/jssi-2015-0463

53. Hijmans RJ, Phillips S, Leathwick J, Maintainer JE. Package “dismo.” 2020.

54. Warren DL, Glor RE, Turelli M. Environmental niche equivalency versus conservatism: Quantitative approaches to niche evolution. Evolution (N Y). Evolution; 2008;62: 28682883. doi:10.1111/j.1558-5646.2008.00482.x

55. Hijmans RJ. Geographic Data Analysis and Modeling [R package raster version 3.4-5]. Comprehensive R Archive Network (CRAN); 2020; Available: https://cran.rproject.org/package=raster

56. Alarcón-Elbal PM, Rodríguez-Sosa MA, Newman BC, Sutton WB. The first record of Aedes vittatus (Diptera: Culicidae) in the Dominican Republic: Public health implications of a potential invasive mosquito species in the Americas. J Med Entomol. Oxford University Press; 2020;57: 2016-2021. doi:10.1093/jme/tjaa128

57. Sudeep AB, Shil P. Aedes vittatus (Bigot) mosquito: An emerging threat to public health [Internet]. Journal of Vector Borne Diseases. Malaria Research Center; 2017. pp. 295-300. doi:10.4103/0972-9062.225833

58. WHO. Technical handbook for dengue surveillance, dengue outbreak prediction/detection and outbreak response ( " model contingency plan " ) WHO Library Cataloguing-inPublication Data. World Heal Organ. 2016; 92. Available: https://apps.who.int/iris/bitstream/handle/10665/250240/9789241549738eng.pdf?sequence $=1$

59. Toledo ME, Rodriguez A, Valdés L, Carrión R, Cabrera G, Banderas D, et al. Evidence on 
medRxiv preprint doi: https://doi.org/10.1101/2021.12.14.21267559; this version posted December 16, 2021. The copyright holder for this

impact of community-based environmental management on dengue transmission in Santiago de Cuba. Trop Med Int Heal. 2011;16: 744-747. doi:10.1111/j.1365-3156.2011.02762.x

60. Vanlerberghe V, Toledo ME, Rodríguez M, Gomez D, Baly A, Benitez JR, et al. Community involvement in dengue vector control: Cluster randomised trial. BMJ. 2009;338: 1477-1479. doi:10.1136/bmj.b1959

61. Andersson N, Nava-Aguilera E, Arosteguí J, Morales-Perez A, Suazo-Laguna H, LegorretaSoberanis J, et al. Evidence based community mobilization for dengue prevention in Nicaragua and Mexico (Camino Verde, the Green Way): Cluster randomized controlled trial. BMJ. BMJ Publishing Group; 2015;351. doi:10.1136/bmj.h3267

62. Tschampl CA, Undurraga EA, Ledogar RJ, Coloma J, Legorreta-Soberanis J, Paredes-Solís S, et al. Cost-effectiveness of community mobilization (Camino Verde) for dengue prevention in Nicaragua and Mexico: A cluster randomized controlled trial. Int J Infect Dis. Elsevier B.V.; 2020;94: 59-67. doi:10.1016/j.ijid.2020.03.026

63. Badolo A, Sombié A, Pignatelli PM, Sanon A, Yaméogo F, Wangrawa DW, et al. Insecticide resistance levels and mechanisms in aedes aegypti populations in and around ouagadougou, Burkina Faso. PLoS Negl Trop Dis. 2019;13. doi:10.1371/journal.pntd.0007439

64. Che-Mendoza A, Medina-Barreiro A, Koyoc-Cardeña E, Uc-Puc V, Contreras-Perera Y, Herrera-Bojórquez J, et al. House screening with insecticide-treated netting provides sustained reductions in domestic populations of Aedes aegypti in Merida, Mexico. Apperson C, editor. PLoS Negl Trop Dis. Public Library of Science; 2018;12: e0006283. doi:10.1371/journal.pntd.0006283

65. Manrique-Saide P, Che-Mendoza A, Barrera-Perez M, Guillermo-May G, Herrera-Bojorquez J, Dzul-Manzanilla F, et al. Use of insecticide-treated house screens to reduce infestations of dengue virus vectors, Mexico. Emerg Infect Dis. 2015;21: 308-311.

doi:10.3201/eid2102.140533 
medRxiv preprint doi: https://doi.org/10.1101/2021.12.14.21267559; this version posted December 16, 2021. The copyright holder for this

66. Dunbar MW, Correa-Morales F, Dzul-Manzanilla F, Medina-Barreiro A, Bibiano-Marín W, Morales-Ríos E, et al. Efficacy of novel indoor residual spraying methods targeting pyrethroid-resistant aedes aegypti within experimental houses. PLoS Negl Trop Dis. Public Library of Science; 2019;13. doi:10.1371/journal.pntd.0007203

67. Dzib-Florez S, Ponce-García G, Medina-Barreiro A, González-Olvera G, Contreras-Perera Y, Castillo-Centeno F Del, et al. Evaluating over-the-counter household insecticide aerosols for rapid vector control of pyrethroid-resistant aedes aegypti. Am J Trop Med Hyg. American Society of Tropical Medicine and Hygiene; 2020;103: 2108-2112. doi:10.4269/ajtmh.200515

68. Manrique-Saide P, Dean NE, Halloran ME, Longini IM, Collins MH, Waller LA, et al. The TIRS trial: Protocol for a cluster randomized controlled trial assessing the efficacy of preventive targeted indoor residual spraying to reduce Aedes-borne viral illnesses in Merida, Mexico. Trials. BioMed Central Ltd; 2020;21: 839. doi:10.1186/s13063-020-04780-7

69. Badolo A, Sombie A, Pignatelli P, Yaméogo F, Sanon A, Wangrawa WD, et al. Baseline data on the bionomics of Aedes aegypti to support dengue control strategies in Burkina Faso. Int J Infect Dis. 2019; doi:10.1016/j.ijid.2018.11.052

70. Weaver SC, Reisen WK. Present and Future Arboviral Threats. Antivir Res. 2010;85: 328. doi:10.1016/j.antiviral.2009.10.008

71. Thavara U, Tawatsin A, Chansang C, Kong-ngamsuk W, Paosriwong S, Boon-Long J, et al. Larval occurrence, oviposition behavior and biting activity of potential mosquito vectors of dengue on Samui Island, Thailand. J Vector Ecol. 2001;26: 172-80. Available: https://pubmed.ncbi.nlm.nih.gov/11813654/

72. CHADEE DD. Landing periodicity of the mosquito Aedes aegypti in Trinidad in relation to the timing of insecticidal space $\square$ spraying. Med Vet Entomol. Med Vet Entomol; 1988;2: 189-192. doi:10.1111/j.1365-2915.1988.tb00071.x 
medRxiv preprint doi: https://doi.org/10.1101/2021.12.14.21267559; this version posted December 16, 2021. The copyright holder for this

73. Captain-Esoah M, Baidoo PK, Frempong KK, Adabie-Gomez D, Chabi J, Obuobi D, et al. Biting behavior and molecular identification of Aedes aegypti (Diptera: Culicidae) subspecies in some selected recent yellow fever outbreak communities in Northern Ghana. J Med Entomol. Oxford University Press; 2020;57: 1239-1245. doi:10.1093/jme/tjaa024

74. Teesdale C. Studies on the bionomics of aëdes aegypti (1.) in its natural habitats in a coastal region of kenya. Bull Entomol Res. Cambridge University Press; 1955;46: 711-742. doi:10.1017/S0007485300039614

75. Casas-Martínez M, Orozco-Bonilla A, Muñoz-Reyes M, Ulloa-García A, Bond JG, ValleMora J, et al. A new tent trap for monitoring the daily activity of Aedes aegypti and Aedes albopictus. J Vector Ecol. J Vector Ecol; 2013;38: 277-288. doi:10.1111/j.1948-

7134.2013.12041.x

76. Powell JR. Mosquitoes on the move [Internet]. Science. American Association for the Advancement of Science; 2016. pp. 971-972. doi:10.1126/science.aal1717

77. McCLELLAND GAH. A worldwide survey of variation in scale pattern of the abdominal tergum of Aedes aegypti (L.) (Diptera: Culicidae). Trans R Entomol Soc London. John Wiley \& Sons, Ltd; 2009;126: 239-259. doi:10.1111/j.1365-2311.1974.tb00853.x

78. Zahouli JBZ, Koudou BG, Müller P, Malone D, Tano Y, Utzinger J. Urbanization is a main driver for the larval ecology of Aedes mosquitoes in arbovirus-endemic settings in southeastern Côte d'Ivoire. Chen C-C, editor. PLoS Negl Trop Dis. Public Library of Science; 2017;11: e0005751. doi:10.1371/journal.pntd.0005751

79. Zahouli JBZ, Koudou BG, Müller P, Malone D, Tano Y, Utzinger J. Effect of land-use changes on the abundance, distribution, and host-seeking behavior of Aedes arbovirus vectors in oil palm-dominated landscapes, southeastern Côte d'Ivoire. PLoS One. 2017;12. doi:10.1371/journal.pone.0189082

80. Abílio AP, Abudasse G, Kampango A, Candrinho B, Sitoi S, Luciano J, et al. Distribution 
medRxiv preprint doi: https://doi.org/10.1101/2021.12.14.21267559; this version posted December 16, 2021. The copyright holder for this

and breeding sites of Aedes aegypti and Aedes albopictus in 32 urban/peri-urban districts of Mozambique: implication for assessing the risk of arbovirus outbreaks. Lenhart A, editor. PLoS Negl Trop Dis. Public Library of Science; 2018;12: e0006692. doi:10.1371/journal.pntd.0006692

81. Ngugi HN, Mutuku FM, Ndenga BA, Musunzaji PS, Mbakaya JO, Aswani P, et al. Characterization and productivity profiles of Aedes aegypti (L.) breeding habitats across rural and urban landscapes in western and coastal Kenya. Parasites and Vectors. BioMed Central Ltd.; 2017;10: 331. doi:10.1186/s13071-017-2271-9

82. Focks DA, Bangs MJ, Church C, Juffrie M, Nalim S. Transmission thresholds and pupal/demographic surveys in Yogyakarta, Indonesia for developing a dengue control strategy based on targeting epidemiologically significant types of water-holding containers. Dengue Bull. 2007;31: 83-102.

83. Morrison AC, Sihuincha M, Stancil JD, Zamora E, Astete H, Olson JG, et al. Aedes aegypti (Diptera: Culicidae) production from nonresidential sites in the Amazonian city of Iquitos, Peru. Ann Trop Med Parasitol. Ann Trop Med Parasitol; 2006;100. doi:10.1179/136485906X105534

84. Abe M, McCall PJ, Lenhart A, Villegas E, Kroeger A. The Buen Pastor cemetery in Trujillo, Venezuela: measuring dengue vector output from a public area. Trop Med Int Heal. Blackwell Publishing Ltd; 2005;10: 597-603. doi:10.1111/j.1365-3156.2005.01428.x

85. Medeiros-Sousa AR, de Oliveira-Christe R, Camargo AA, Scinachi CA, Milani GM, Urbinatti PR, et al. Influence of water's physical and chemical parameters on mosquito (Diptera: Culicidae) assemblages in larval habitats in urban parks of São Paulo, Brazil. Acta Trop. Elsevier B.V.; 2020;205: 105394. doi:10.1016/j.actatropica.2020.105394

86. Overgaard HJ, Olano VA, Jaramillo JF, Matiz MI, Sarmiento D, Stenström TA, et al. A cross-sectional survey of Aedes aegypti immature abundance in urban and rural household 
medRxiv preprint doi: https://doi.org/10.1101/2021.12.14.21267559; this version posted December 16, 2021. The copyright holder for this

containers in central Colombia. Parasites and Vectors. BioMed Central Ltd.; 2017;10: 356.

doi:10.1186/s13071-017-2295-1

87. Reiner RC, Stoddard ST, Vazquez-Prokopec GM, Astete H, Perkins TA, Sihuincha M, et al. Estimating the impact of city-wide Aedes aegypti population control: An observational study in Iquitos, Peru. PLoS Negl Trop Dis. Public Library of Science; 2019;13. doi:10.1371/journal.pntd.0007255

88. LaCon G, Morrison AC, Astete H, Stoddard ST, Paz-Soldan VA, Elder JP, et al. Shifting Patterns of Aedes aegypti Fine Scale Spatial Clustering in Iquitos, Peru. PLoS Negl Trop Dis. Public Library of Science; 2014;8. doi:10.1371/journal.pntd.0003038

89. Bonnet E, Fournet F, Benmarhnia T, Ouedraogo S, Dabiré R, Ridde V. Impact of a community-based intervention on Aedes aegypti and its spatial distribution in Ouagadougou, Burkina Faso. Infect Dis Poverty. BioMed Central Ltd.; 2020;9. doi:10.1186/s40249-02000675-6

90. Bowman LR, Runge-Ranzinger S, McCall PJ. Assessing the Relationship between Vector Indices and Dengue Transmission: A Systematic Review of the Evidence. PLoS Neglected Tropical Diseases. 2014. doi:10.1371/journal.pntd.0002848

91. Rodriguez-Figueroa L, Rigau-Perez JG, Suarez EL, Reiter P. Risk factors for dengue infection during an outbreak in Yanes, Puerto Rico in 1991. Am J Trop Med Hyg. 1995; doi:10.4269/ajtmh.1995.52.496

92. Benelli G, Beier JC. Current vector control challenges in the fight against malaria [Internet]. Acta Tropica. Elsevier B.V.; 2017. pp. 91-96. doi:10.1016/j.actatropica.2017.06.028

93. Esu E, Lenhart A, Smith L, Horstick O. Effectiveness of peridomestic space spraying with insecticide on dengue transmission; systematic review. Trop Med Int Heal. John Wiley \& Sons, Ltd; 2010;15: 619-631. doi:10.1111/j.1365-3156.2010.02489.x

94. Sombié A, Saiki E, Yaméogo F, Sakurai T, Shirozu T, Fukumoto S, et al. High frequencies 
medRxiv preprint doi: https://doi.org/10.1101/2021.12.14.21267559; this version posted December 16, 2021. The copyright holder for this preprint (which was not certified by peer review) is the author/funder, who has granted medRxiv a license to display the preprint in perpetuity. All rights reserved. No reuse allowed without permission.

of F1534C and V1016I kdr mutations and association with pyrethroid resistance in Aedes aegypti from Somgandé ( Ouagadougou ), Burkina Faso. Trop Med Health. Tropical Medicine and Health; 2019;5: 4-11.

95. Utarini A, Indriani C, Ahmad RA, Tantowijoyo W, Arguni E, Ansari MR, et al. Efficacy of Wolbachia-Infected Mosquito Deployments for the Control of Dengue. N Engl J Med. Massachusetts Medical Society; 2021;384: 2177-2186. doi:10.1056/nejmoa2030243 
Supplementary Tables and Figures 
S1Table. Household characteristics and demography in the three localities during the two years of collection, 2016 and 2017.

\begin{tabular}{|c|c|c|c|c|c|c|c|c|c|c|c|c|}
\hline STATISTIC & Aug-16 & Sep-16 & Oct-16 & Aug-17 & Sep-17 & Oct-17 & Aug-16 & Sep-16 & Oct-16 & Aug-17 & Sep-17 & Oct-17 \\
\hline Premises visited & 114 & 115 & 158 & 49 & 53 & 41 & 114 & 115 & 158 & 49 & 53 & 41 \\
\hline Number of residents & 635 & 621 & 748 & 288 & 230 & 205 & 635 & 621 & 748 & 288 & 230 & 205 \\
\hline $\begin{array}{l}\text { Premises positive for adult } A e . \\
\text { aegypti }\end{array}$ & $\begin{array}{c}93 \\
(82.3 \%)\end{array}$ & $\begin{array}{c}104 \\
(89.7)\end{array}$ & $\begin{array}{c}105 \\
(66.5 \%)\end{array}$ & $\begin{array}{c}41 \\
(83.7 \%)\end{array}$ & $\begin{array}{c}43 \\
(79.6 \%)\end{array}$ & $\begin{array}{c}24 \\
(58.5 \%)\end{array}$ & $\begin{array}{c}84 \\
(66.1 \%)\end{array}$ & $\begin{array}{c}128 \\
(69.2 \%)\end{array}$ & $\begin{array}{c}36 \\
(44.4 \%)\end{array}$ & $\begin{array}{c}77 \\
(77.0 \%)\end{array}$ & $\begin{array}{c}72 \\
(71.3 \%)\end{array}$ & $\begin{array}{c}36 \\
(39.1 \%)\end{array}$ \\
\hline $\begin{array}{l}\text { Premises positive for pupae and } \\
\text { larvae (HI) }\end{array}$ & $\begin{array}{c}67 \\
(58.8 \%)\end{array}$ & $\begin{array}{c}54 \\
(47.4 \%)\end{array}$ & $\begin{array}{c}19 \\
(16.7 \%)\end{array}$ & $\begin{array}{c}26 \\
(22.8 \%)\end{array}$ & $\begin{array}{c}20 \\
(17.5 \%)\end{array}$ & $0(0.0 \%)$ & $\begin{array}{c}67 \\
(58.8 \%)\end{array}$ & $\begin{array}{c}54 \\
(47.4 \%)\end{array}$ & $\begin{array}{c}19 \\
(16.7 \%)\end{array}$ & $\begin{array}{c}26 \\
(22.8 \%)\end{array}$ & $\begin{array}{c}20 \\
(17.5 \%)\end{array}$ & $0(0.0 \%)$ \\
\hline $\begin{array}{l}\text { Premises positive for pupae } \\
\text { (HPI) }\end{array}$ & $\begin{array}{c}49 \\
(43.0 \%)\end{array}$ & $\begin{array}{c}44 \\
(38.3 \%)\end{array}$ & $\begin{array}{c}10 \\
(6.3 \%)\end{array}$ & $\begin{array}{c}21 \\
(42.9 \%)\end{array}$ & $\begin{array}{c}11 \\
(20.8 \%)\end{array}$ & $0(0.0 \%)$ & $\begin{array}{c}49 \\
(43.0 \%)\end{array}$ & $\begin{array}{c}44 \\
(38.3 \%)\end{array}$ & $\begin{array}{c}10 \\
(6.3 \%)\end{array}$ & $\begin{array}{c}21 \\
(42.9 \%)\end{array}$ & $\begin{array}{c}11 \\
(20.8 \%)\end{array}$ & $0(0.0 \%)$ \\
\hline No. containers with Water & 167 & 144 & 58 & 114 & 61 & 0 & 167 & 144 & 58 & 114 & 61 & 0 \\
\hline $\begin{array}{l}\text { No. containers positive for } \\
\text { pupae and larvae }(\mathrm{CI})\end{array}$ & $\begin{array}{c}94 \\
(56.3 \%)\end{array}$ & $\begin{array}{c}101 \\
(70.1 \%)\end{array}$ & $\begin{array}{c}27 \\
(46.6 \%)\end{array}$ & $\begin{array}{c}71 \\
(62.3 \%)\end{array}$ & $\begin{array}{c}43 \\
(70.5 \%)\end{array}$ & $0(-)$ & $\begin{array}{c}94 \\
(56.3 \%)\end{array}$ & $\begin{array}{c}101 \\
(70.1 \%)\end{array}$ & $\begin{array}{c}27 \\
(46.6 \%)\end{array}$ & $\begin{array}{c}71 \\
(62.3 \%)\end{array}$ & $\begin{array}{c}43 \\
(70.5 \%)\end{array}$ & $0(-)$ \\
\hline $\begin{array}{l}\text { No. containers positive for } \\
\text { pupae }(\mathrm{CPI})\end{array}$ & $\begin{array}{c}65 \\
(38.9 \%)\end{array}$ & $\begin{array}{c}64 \\
(44.4 \%)\end{array}$ & $\begin{array}{c}11 \\
(0.19)\end{array}$ & $\begin{array}{c}50 \\
(43.9 \%)\end{array}$ & $\begin{array}{c}22 \\
(36.1 \%)\end{array}$ & $0(-)$ & $\begin{array}{c}65 \\
(38.9 \%)\end{array}$ & $\begin{array}{c}64 \\
(44.4 \%)\end{array}$ & $\begin{array}{c}11 \\
(0.19)\end{array}$ & $\begin{array}{c}50 \\
(43.9 \%)\end{array}$ & $\begin{array}{c}22 \\
(36.1 \%)\end{array}$ & $0(-)$ \\
\hline Total number of pupae & 690 & 965 & 99 & 616 & 202 & 0 & 690 & 965 & 99 & 616 & 202 & 0 \\
\hline Pupae per person index & 1.1 & 1.6 & 0.1 & 2.1 & 0.9 & 0.0 & 1.1 & 1.6 & 0.1 & 2.1 & 0.9 & 0.0 \\
\hline Breteau Index & 48.0 & 51.5 & 13.8 & 36.2 & 21.9 & 0.0 & 48.0 & 51.5 & 13.8 & 36.2 & 21.9 & 0.0 \\
\hline
\end{tabular}




\section{STATISTIC}

Premises visited

Premises positive for adult Ae.aegypti

Number of residents

Premises positive for pupae and larvae (HI)

Premises positive for pupae (HPI)

No. containers with Water

No. containers positive for pupae and larvae (CI)

No. containers positive for pupae (CPI)

Total number of pupae

Pupae per person index

Breteau Index
Goundry

\begin{tabular}{|c|c|c|c|c|c|}
\hline Aug-16 & Sep-16 & Oct-16 & Aug-17 & Sep-17 & Oct-17 \\
\hline 114 & 115 & 158 & 49 & 53 & 41 \\
\hline $\begin{array}{c}38 \\
(18.9 \%) \\
\end{array}$ & $\begin{array}{c}27 \\
(18.5 \%) \\
\end{array}$ & $\begin{array}{c}3 \\
(6.4 \%) \\
\end{array}$ & $\begin{array}{c}18 \\
(34.0 \%) \\
\end{array}$ & $\begin{array}{c}22 \\
(32.8 \%) \\
\end{array}$ & $\begin{array}{c}10 \\
(18.5 \%) \\
\end{array}$ \\
\hline 635 & 621 & 748 & 288 & 230 & 205 \\
\hline $\begin{array}{c}67 \\
(58.8 \%)\end{array}$ & $\begin{array}{c}54 \\
(47.4 \%)\end{array}$ & $\begin{array}{c}19 \\
(16.7 \%)\end{array}$ & $\begin{array}{c}26 \\
(22.8 \%)\end{array}$ & $\begin{array}{c}20 \\
(17.5 \%)\end{array}$ & $0(0.0 \%)$ \\
\hline $\begin{array}{c}49 \\
(43.0 \%)\end{array}$ & $\begin{array}{c}44 \\
(38.3 \%) \\
\end{array}$ & $\begin{array}{c}10 \\
(6.3 \%)\end{array}$ & $\begin{array}{c}21 \\
(42.9 \%)\end{array}$ & $\begin{array}{c}11 \\
(20.8 \%)\end{array}$ & $0(0.0 \%)$ \\
\hline 167 & 144 & 58 & 114 & 61 & 0 \\
\hline $\begin{array}{c}94 \\
(56.3 \%)\end{array}$ & $\begin{array}{c}101 \\
(70.1 \%)\end{array}$ & $\begin{array}{c}27 \\
(46.6 \%)\end{array}$ & $\begin{array}{c}71 \\
(62.3 \%)\end{array}$ & $\begin{array}{c}43 \\
(70.5 \%)\end{array}$ & $0(-)$ \\
\hline $\begin{array}{c}65 \\
(38.9 \%) \\
\end{array}$ & $\begin{array}{c}64 \\
(44.4 \%) \\
\end{array}$ & $\begin{array}{c}11 \\
(0.19) \\
\end{array}$ & $\begin{array}{c}50 \\
(43.9 \%) \\
\end{array}$ & $\begin{array}{c}22 \\
(36.1 \%)\end{array}$ & $0(-)$ \\
\hline 690 & 965 & 99 & 616 & 202 & 0 \\
\hline 1.1 & 1.6 & 0.1 & 2.1 & 0.9 & 0.0 \\
\hline 48.0 & 51.5 & 13.8 & 36.2 & 21.9 & 0.0 \\
\hline
\end{tabular}


S2Table. Average number per house, the $95 \%$ confidence limits [in brackets] and the total number of mosquitoes (in parenthesis) of Aedes aegypti mosquitoes collected in the study localities in 2016 and 2017

\begin{tabular}{|c|c|c|c|c|c|c|}
\hline \multirow[b]{3}{*}{ Location } & \multicolumn{6}{|c|}{ Locality } \\
\hline & \multicolumn{2}{|c|}{ 1200LG (urban) } & \multicolumn{2}{|c|}{ Tabtenga (peri-urban) } & \multicolumn{2}{|c|}{ Goundry (rural) } \\
\hline & 2016 & 2017 & 2016 & 2017 & 2016 & 2017 \\
\hline \multirow{2}{*}{ Indoor } & $0.51(426)$ & $0.37(123)$ & $0.48(333)$ & $0.67(371)$ & $0.04(25)$ & $0.05(17)$ \\
\hline & {$[0.41-0.61]$} & {$[0.25-0.49]$} & {$[0.4-0.57]$} & {$[0.54-0.81]$} & {$[0.02-0.06]$} & [0.02-0.09] \\
\hline \multirow{2}{*}{ Outdoor } & $1.79(1,373)$ & $1.86(659)$ & $0.83(643)$ & $0.89(592)$ & $0.16(112)$ & $0.28(126)$ \\
\hline & [1.54-2.07] & [1.46-2.33] & [0.69-0.98] & {$[0.71-1.07]$} & {$[0.12-0.21]$} & [0.19-0.39] \\
\hline
\end{tabular}


S3Table. Average number of mosquitoes per house, the 95\% confidence limits [in brackets] and the total number (in parenthesis) collected in the morning (am) and in the afternoon (pm) of the three main species of mosquito collected in the study localities in 2016 and 2017.

\begin{tabular}{|c|c|c|c|c|c|c|}
\hline \multirow[t]{3}{*}{ collection time } & \multicolumn{6}{|l|}{ Locality } \\
\hline & \multicolumn{2}{|c|}{ 1200LG (Urban) } & \multicolumn{2}{|c|}{ Tabtenga (peri-urban) } & \multicolumn{2}{|c|}{ Goundry (Rural) } \\
\hline & 2016 & 2017 & 2016 & 2017 & 2016 & 2017 \\
\hline \multirow[t]{2}{*}{$\mathrm{am}$} & $1.37(1,123)$ & $1.27(418)$ & $0.64(572)$ & $0.86(467)$ & $0.08(49)$ & $0.1(64)$ \\
\hline & [1.15-1.61] & {$[0.94-1.66]$} & {$[0.54-0.75]$} & {$[0.7-1.03]$} & [0.04-0.11] & {$[0.04-0.17]$} \\
\hline \multirow[t]{2}{*}{$\mathrm{pm}$} & $0.8(688)$ & $0.78(364)$ & $0.63(404)$ & $0.7(496)$ & $0.11(88)$ & $0.21(79)$ \\
\hline & {$[0.67-0.94]$} & {$[0.59-1]$} & {$[0.52-0.76]$} & {$[0.56-0.85]$} & {$[0.07-0.14]$} & [0.14-0.29] \\
\hline
\end{tabular}


S4Table. Number of bloodfed, number of PCR-tested, and bloodmeal sources of Aedes aegypti mosquitoes per locality and per year.

\begin{tabular}{cccccccc}
\hline Year & Locality & $\begin{array}{c}\text { Total } \\
\text { collected }\end{array}$ & $\begin{array}{c}\text { Total } \\
\text { Tested }\end{array}$ & Human & Dog & $\begin{array}{c}\text { Human+ } \\
\text { Dog }\end{array}$ & $\begin{array}{c}\text { Dog+ } \\
\text { Cow }\end{array}$ \\
\hline 2016 & 1200LG & 304 & 104 & 55 & 2 & 2 & 0 \\
& Tabtenga & 202 & 106 & 61 & 1 & 3 & 0 \\
& Goundry & 18 & 14 & 5 & 1 & 0 & 1 \\
& 1200LG & 101 & 101 & 27 & 9 & 0 & 0 \\
& Tabtenga & 166 & 166 & 10 & 3 & 0 & 0 \\
& Rural & 7 & 7 & 0 & 0 & 0 & 0 \\
\hline
\end{tabular}


S5Table. Relative abundance of mosquito species collected as larvae and pupae during routine house sampling in each locality and year.

Table shows the mean number per house (and total number collected) for each species detected and the confidence limits in brackets. All

identified individuals were adults that had been reared in the laboratory from field-collected immature stages.

\begin{tabular}{|c|c|c|c|c|c|c|}
\hline \multirow[t]{2}{*}{ Species } & \multicolumn{2}{|l|}{$1200 \mathrm{LG}$} & \multicolumn{2}{|l|}{ Tabtenga } & \multicolumn{2}{|l|}{ Goundry } \\
\hline & 2016 & 2017 & 2016 & 2017 & 2016 & 2017 \\
\hline \multirow[t]{2}{*}{ Aedes aegypti (pupae) } & $1.06(601)$ & $2.44(1,138)$ & $2.09(1,492)$ & $3.64(2,457)$ & $0.54(579)$ & $1.14(1994)$ \\
\hline & {$[1.83-2.31]$} & [2.69-4.39] & {$[2.59-3.69]$} & {$[3.58-6.02]$} & {$[1.37-1.75]$} & {$[1.74-2.62]$} \\
\hline \multirow[t]{2}{*}{ Aedes aegypti (larvae) } & $19.62(9,317)$ & $43.26(11,373)$ & $27.96(11,286)$ & $37.84(14,550)$ & $3.36(3,471)$ & $5.2(5,420)$ \\
\hline & {$[17.31-24.56]$} & {$[34.03-57.56]$} & {$[23.87-35.15]$} & {$[30.15-50.05]$} & {$[3.56-5.35]$} & {$[4.77-8.05]$} \\
\hline \multirow[t]{2}{*}{ Aedes vittatus (pupae) } & $(0)$ & (0) & $0.01(2)$ & $0.01(3)$ & $0.47(570)$ & $0.64(1,006)$ \\
\hline & $(0)$ & (0) & {$[0.99-1.02]$} & {$[0.99-1.03]$} & {$[1.3-1.65]$} & {$[1.38-1.94]$} \\
\hline \multirow[t]{2}{*}{ Aedes vittatus (larvae) } & $0.003(1)$ & $0.02(269)$ & $0.02(8)$ & $0.03(15)$ & $1.93(2,972)$ & $2.40(2,878)$ \\
\hline & {$[0-1.00]$} & {$[0-1.04]$} & {$[0.004 .1 .04]$} & {$[0-1.06]$} & $[1.39-3.59)]$ & {$[1.68-4.30]$} \\
\hline \multirow[t]{2}{*}{ Culex quinquefasciatus (pupae) } & $0.05(248)$ & $0.02(3)$ & $0.16(660)$ & $0.14(163)$ & $0.04(20)$ & $0.05(24)$ \\
\hline & {$[1-1.1]$} & {$[1-1.04]$} & {$[1.06-1.27]$} & {$[1.03-1.25]$} & [1.01-1.07] & [1.01-1.09] \\
\hline \multirow[t]{2}{*}{ Culex quinquefasciatus (larvae) } & $0.4(719)$ & $0.48(269)$ & $1.03(1,241)$ & $0.48(682)$ & $0.33(275)$ & $0.47(440)$ \\
\hline & {$[1.26-1.55]$} & {$[1.26-1.73]$} & {$[1.73-2.38]$} & {$[1.27-1.74]$} & {$[1.21-1.46]$} & {$[1.29-1.68]$} \\
\hline Culex decens & $(154)$ & $(300)$ & $(240)$ & $(608)$ & $(150)$ & $(660)$ \\
\hline Culex nebulosus & $(142)$ & $(62)$ & $(23)$ & (2) & (38) & (1899) \\
\hline Culex sp. & $(59)$ & (4) & $(5)$ & (13) & (197) & $(2,892)$ \\
\hline Aedes hirsutus & $(0)$ & $(0)$ & (0) & $(0)$ & (2) & $(0)$ \\
\hline Aedes metallicus & $(0)$ & $(0)$ & $(0)$ & $(0)$ & (2) & $(0)$ \\
\hline
\end{tabular}




\begin{tabular}{|c|c|c|c|c|c|c|}
\hline Other Aedes & $(0)$ & $(0)$ & (5) & $(0)$ & (14) & $(0)$ \\
\hline Anopheles gambiae s.l. & (2) & 0 & $(21)$ & (4) & (6) & (4) \\
\hline Other Anopheles & (1) & $(0)$ & (0) & $(0)$ & (1) & $(0)$ \\
\hline
\end{tabular}


S6Table. Generalised linear mixed model of Aedes aegypti larval density. Reference factor levels of predictors are shown in square brackets, with beta effect size estimates, confidence intervals, z-value and probabilities for predictors included in the minimal model. Significant predictor terms are shown in bold and non-significant terms, not included in the model, are listed as a footnote.

\begin{tabular}{|c|c|c|c|c|}
\hline Predictors & Estimate & $95 \% \mathrm{CL}$ & z-value & $\operatorname{Pr}(>|z|)$ \\
\hline Intercept & 2.88 & {$[2.35-3.40]$} & 10.72 & $<0.001$ \\
\hline \multicolumn{5}{|l|}{ Year [2016] } \\
\hline 2017 & 0.33 & {$[0.10-0.57]$} & 2.76 & 0.006 \\
\hline \multicolumn{5}{|l|}{ Locality [Goundry] } \\
\hline Tabtenga & $\mathbf{0 . 3 3}$ & {$[0.50-1.04]$} & 2.76 & 0.006 \\
\hline 1200LG & 0.77 & {$[0.34-0.90]$} & 5.51 & $<0.001$ \\
\hline \multicolumn{5}{|l|}{ Month [August] } \\
\hline October & -0.18 & {$[-0.61-0.25]$} & -0.83 & 0.405 \\
\hline September & 0.31 & {$[0.05-0.56]$} & 2.36 & 0.018 \\
\hline 2-day rainfall & 0.01 & {$[0.00-0.02]$} & 1.72 & 0.086 \\
\hline Water level (cm) & 0.02 & {$[\mathbf{0 . 0 0 - 0 . 0 3 ]}$} & 2.30 & 0.022 \\
\hline \multicolumn{5}{|l|}{ Container [Medium container] } \\
\hline Large container & 0.30 & {$[-0.01-0.61]$} & 1.90 & 0.057 \\
\hline Others & 0.25 & {$[-0.72-1.23]$} & 0.51 & 0.610 \\
\hline Small container & 0.18 & {$[-0.13-0.48]$} & 1.13 & 0.260 \\
\hline Car tire & 0.35 & {$[0.04-0.66]$} & 2.21 & 0.027 \\
\hline Animal drinking trough & 0.28 & {$[-0.09-0.66]$} & 1.48 & 0.140 \\
\hline
\end{tabular}

Non-significant terms: temperature, container utility, container material, container height, water volume, number of residents, adult mosquito abundance, container position (shady/ sunny). 
S7Table. Generalised linear mixed model of Aedes aegypti pupal density. Reference factor levels of predictors are shown in square brackets, with beta effect size estimates, confidence intervals, z-value and probabilities for predictors included in the minimal model. Significant predictor terms are shown in bold and non-significant terms, not included in the model, are listed as a footnote.

\begin{tabular}{lcccc}
\hline Predictors & Estimate & $95 \% \mathrm{CL}$ & $\mathrm{z}$-value & $\operatorname{Pr}(>|\mathrm{z}|)$ \\
\hline Intercept & $\mathbf{6 . 0 1}$ & {$[\mathbf{3 . 0 5 - 8 . 9 7}]$} & $\mathbf{3 . 9 8}$ & $<\mathbf{0 . 0 0 1}$
\end{tabular}

Locality [Goundry]

Tabtenga

1200LG

Temp mean

Container [Medium container]

Large container

$-0.10$

0.35

$-0.17$

$-0.17$

0.71

$-0.43$

[-0.84--0.01]

$-2.03$

[0.01-0.04]

2.41

$-0.86$

$-2.72$

0.007

Car tire

0.02
[-0.59-0.39]

$-0.41$

0.684

$[-1.15-1.86]$

0.46

0.646

[-0.67-0.33]

$-0.68$

0.495

[-0.67-0.32]

$-0.69$

0.491

2.12

0.034
Container utility [No]

Adult abundance

2.54

0.043

0.02

Non-significant terms: Year, month, Temperature, container utility, container material, container height, water volume, water level, number of residents, cumulative rainfall of 7 previous days, container position (shady/sunny). 
medRxiv preprint doi: https://doi.org/10.1101/2021.12.14.21267559; this version posted December 16, 2021. The copyright holder for this preprint (which was not certified by peer review) is the author/funder, who has granted medRxiv a license to display the preprint in perpetuity.

All rights reserved. No reuse allowed without permission.

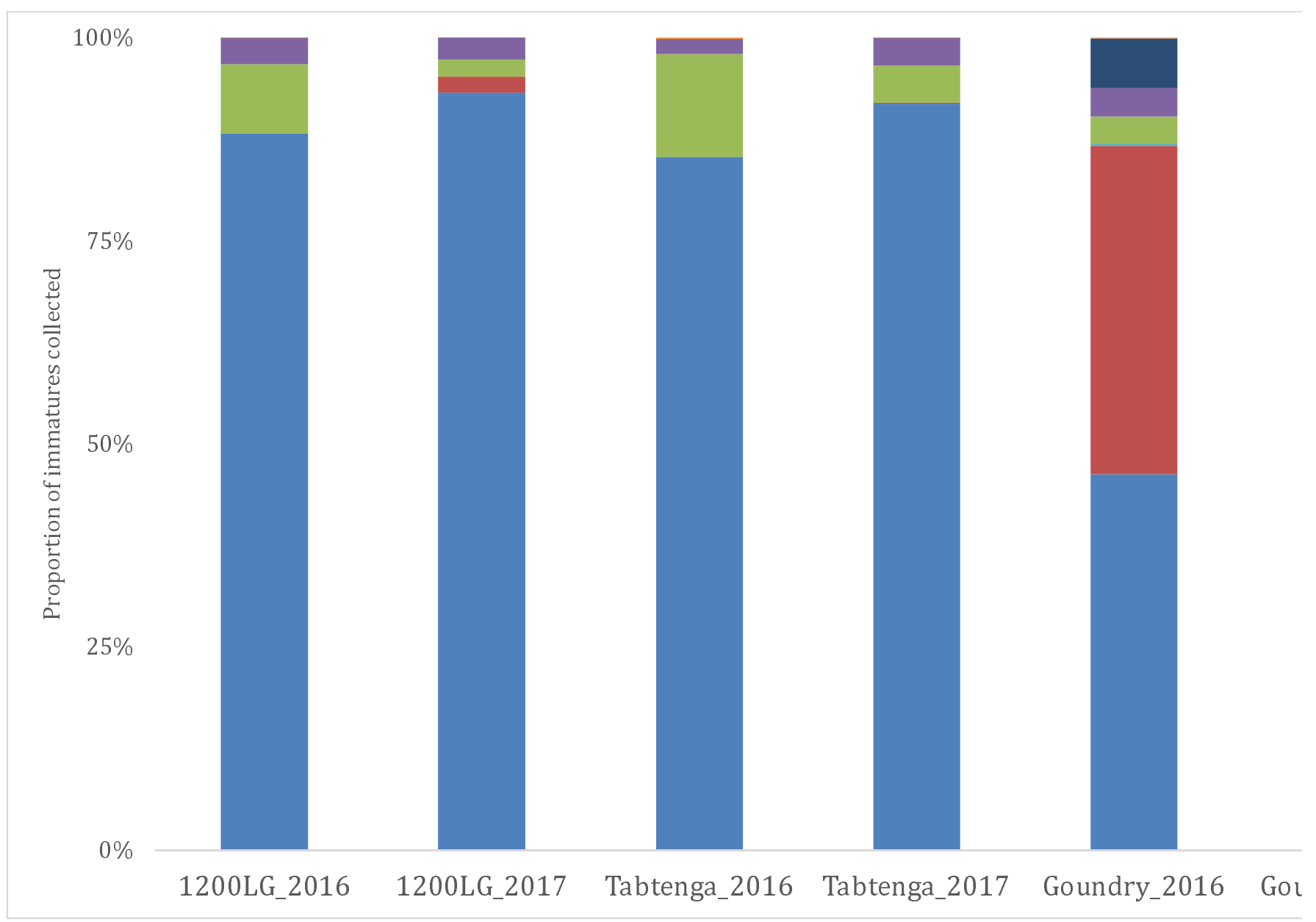

2 S1Figure. Mosquito community diversity in immature collections in each location and year. 


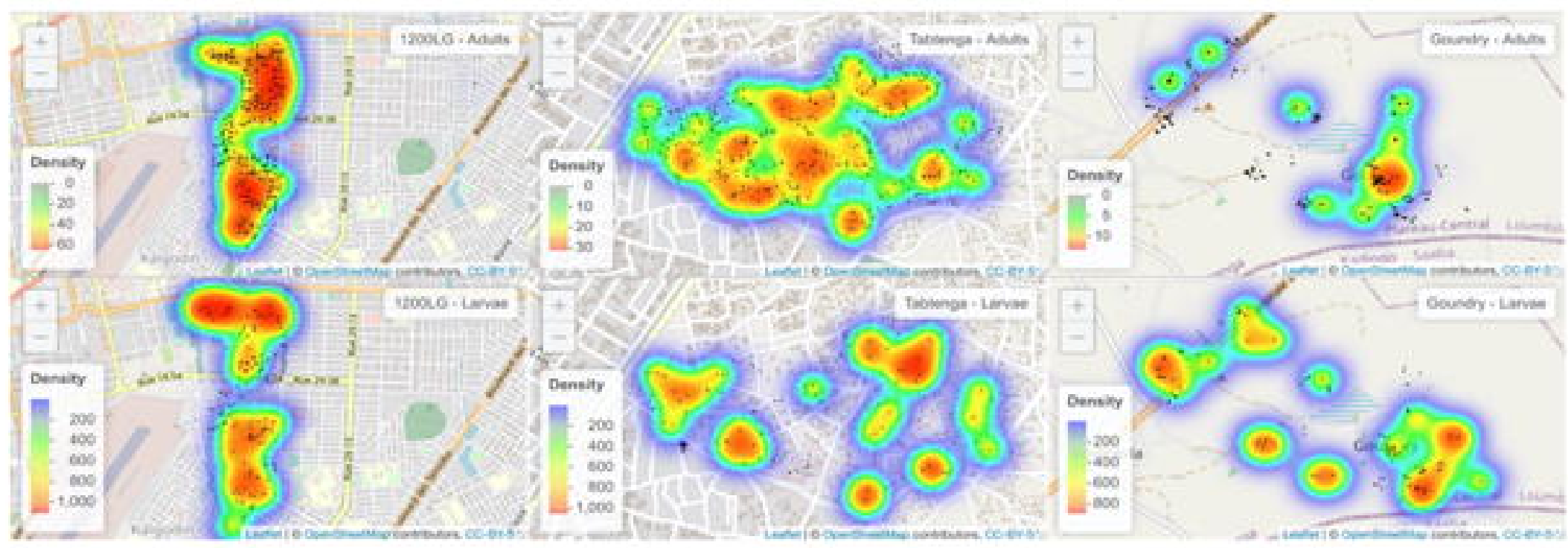



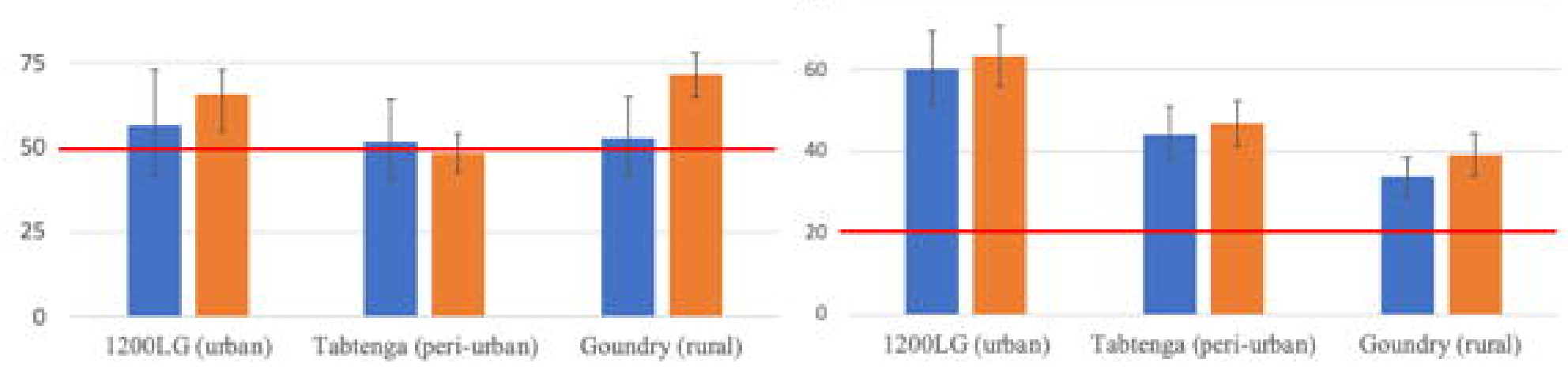
House index
= $2016=2017$

Pupae index

a 2016 = 2017
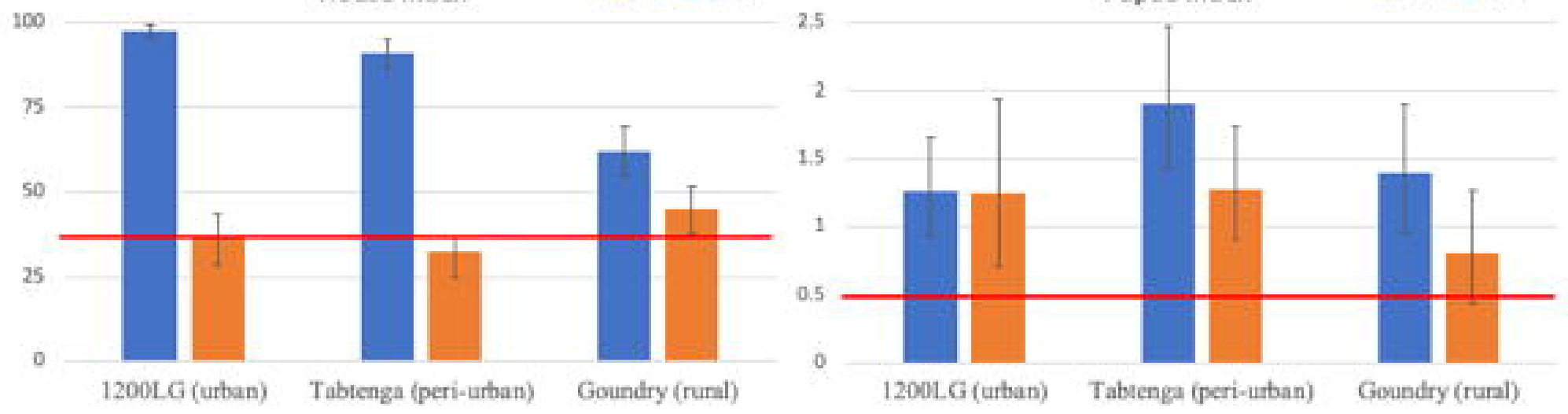

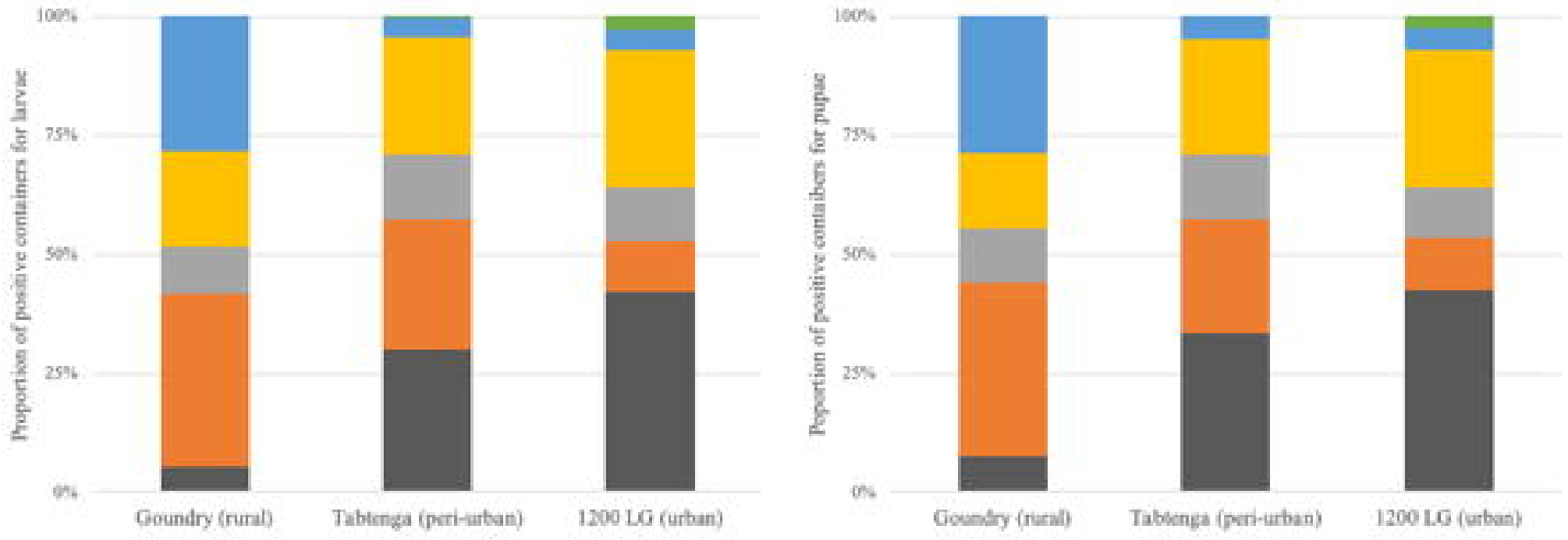
2.5

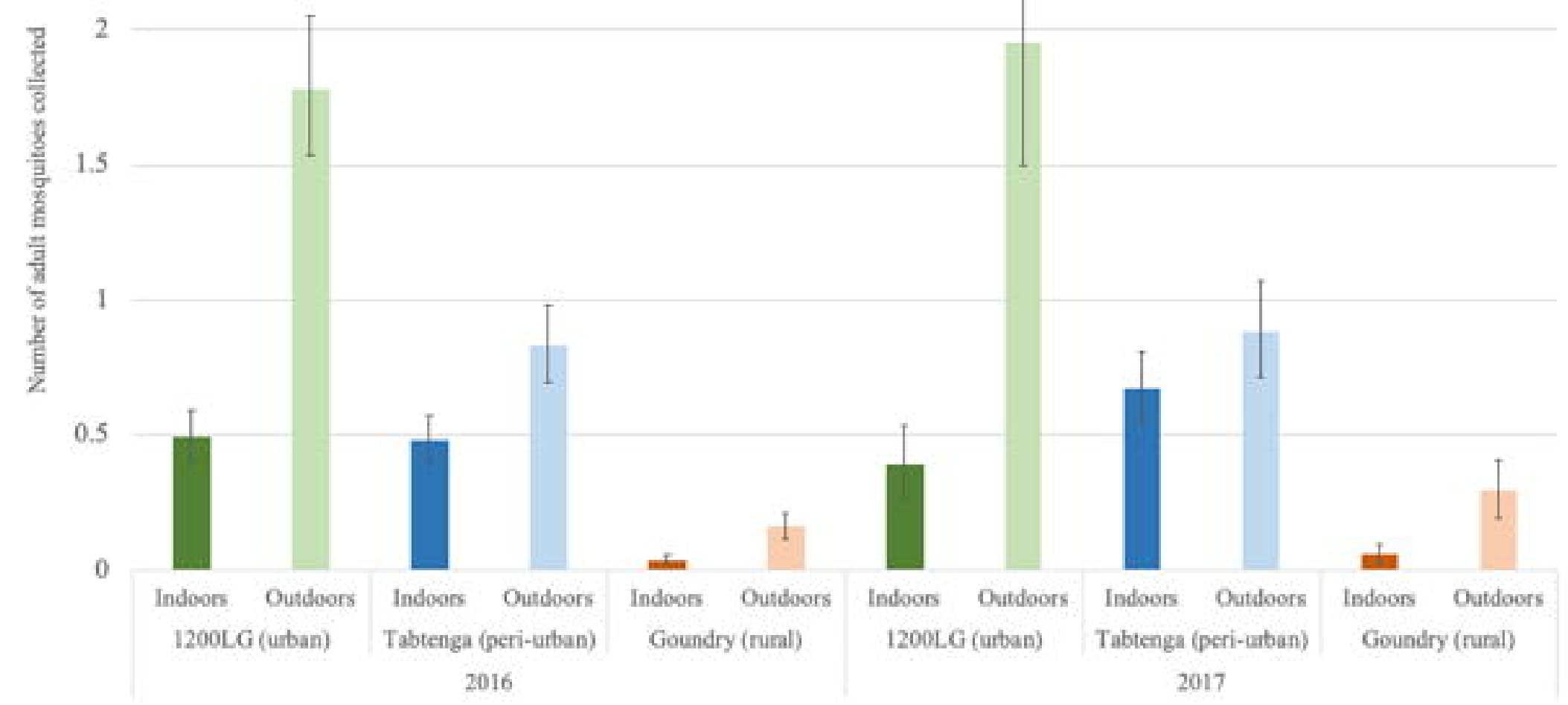

